\title{
Application of Biosurfactant Producing Microorganisms to Remediate Heavy Metal Pollution in El-Gabal El-Asfar Area
}

\author{
Rabaa Y. Yaseen*, Samah M. Abd El-Aziz ${ }^{1}$, Doaa T. Eissa ${ }^{2} \&$ Ahmed M. Abou-Shady $^{2 * *}$
}

\begin{abstract}
In the present study, the effects of biosurfactant producing cells of different bacterial species namely Pseudochrobactrum lubricantisa, Lysobacter novalis, and crude biosurfactant extracted from Aspergillus niger were investigated as a cheap source to alleviate the availability of $\mathbf{P b}^{2+}$ for plants grown in El-Gabal El-Asfar area, Egypt. This is owing to these areas are basically depend on the reused wastewater for irrigation. Biosurfactant producing microorganisms were isolated from three different farms aged for 20, 40, and 60 years. The obtained results showed that, the biosurfactant producing bacteria decreased the availability of $\mathrm{Pb}^{2+}$ in the outlet leachate during the leaching columns experiments. In contrast, $\mathrm{Sr}^{2+}$ leachate showed the reverse trend that was observed with $\mathbf{P b}^{2+}$. Taguchi approach indicated that, the mechanisms of biosurfactant producing bacteria are very complicated and interfused with each other. The most factors affected the available form of $\mathbf{P b}^{2+}$ and $\mathbf{P b}^{2+}$ existed in organic form was $\mathbf{P b}^{2+}$ concentrations, however the exchangeable $\mathbf{P b}^{2+}$, $\mathrm{Pb}^{2+}$ bond to carbonate, $\mathbf{P b}^{2+}$ bond to sulfate, and plant content the most influential factors was biosurfactant producing bacteria. The most influential factors affected NPK uptake by watercress were found to take the following sequence biosurfactant producing bacteria > $\mathrm{Sr}^{2+}$ doses $>\mathrm{Pb}^{2+}$ doses.
\end{abstract}

Keywords: Biosurfactant; Heavy metals; Remediation; $\mathrm{Pb}^{2+} ; \mathrm{Sr}^{2+}$; Taguchi approach

\section{INTRODUCTION}

Water scarcity is in arid and semi-arid countries persuaded farmers for reusing drainage wastewater as alternative source for irrigation. The Egyptian government has established El-Sallam canal project that depends on blending of drainage wastewater (El-Serw and Hadous drainages) and Nile River water at constant ratio 1:1 to overcome water scarcity( Abou-Shady, 2017). Also, soils close to industrial areas such as Burg El Arab have been contaminated with rare inorganic contaminates such as vanadium (Eissa et al., 2017). Accordingly, industrial and rural areas have been contaminated with inorganic and organic contaminates that is represent a threat to human being and animals. The main pollution source in industrial areas is the untreated wastewater. So that, the treatment of industrial wastewater should be carried out before the outlet discharge (Peng et al., 2011; Abou-Shady, 2016a; Abou-Shady, 2016b; Abou-Shady, 2017; Eissa et al., 2017).

Several approaches have been introduced to treat heavy metal polluted soils such as electrokinetic remediation, chemical washing, precipitation, etc (Abou-Shady, 2012; Almeria et al., 2012a; Abou-Shady et al., 2018). Heavy metals interact with humic substances (humic and fulvic acids) containing soils and comply with its distribution in soil profile (Abou-Shady, 2008; Khalil et al., 2009). Biosurfactant producing microorganisms is an emerging technique that may be produced by different sources such as microorganisms, plants, and animals. Biosurfactant producing microorganisms has a direct influence on several factors that control the behavior of heavy metals such as sorption, ion exchange, electrostatic interaction, resistance to aqueous phase transport, dissolution, rate limited mass transfer, and precipitation. The biosurfactant producing microorganisms possesses a biodegradable behavior compared with synthetic components that is considered friendly to environmental. Another advantage relieves from biosurfactant producing microorganisms that is considered a cost effective material produces in situ (Milleer, 1995; Franzetti et al. 2014).

Several attempts have been carried out to restore heavy metal $(\mathrm{Zn}, \mathrm{Cu}, \mathrm{Cr}, \mathrm{Hg}, \mathrm{Cd}$ and $\mathrm{Pb}$ ) containing wastewater and polluted soil using the biosurfactant producing microorganisms (Zouboulis et al. 2003; Yuan et al., 2008; Chen et al. 2011; Elouzilet al., 2102; Huang and Liu, 2013). The efficiency of the biosurfactant producing microorganisms has been improved using ethylene diamine tetra acetic acid (EDTA) and citric acid. On the other hand, adding the biosurfactant producing microorganisms to soils

\footnotetext{
${ }^{1}$ Soil Fertility and Microbiology Department, Water Resources and

Desert Soils Division, Desert Research Center, El-Matariya 11753, Cairo, Egypt.

2-Laboratory of Water \& Soil Chemistry, Water Resources and Desert

Soils Division, Desert Research Center, El-Matariya 11753, Cairo, Egypt.

* Corresponding author. Tel. +201003683954

E-mail address: rabaa.yaseen@yahoo.com

** Corresponding author. Tel. +201017442805

E-mail address: aboushady@ymail.com

Received Januury28, 2018, Accepted February21, 2018
} 
contaminated with heavy metals is considered an effective factor to improve phytoremediation endeavor (Slizovskiy et al., 2011; Rajkumar et al., 2012).

The objectives of this study were to study the impact of the biosurfactant producing microorganisms on heavy metals containing polluted soil using soil collected from El-Gabal El-Asfar area, Egypt as representative of polluted soils in Egypt. To identify the influence of biosurfactant producing bacteria; the changes of dominant species of $\mathrm{Pb}^{2+}$ in the studied soils were studied. Also, the effects of bacteria species, $\mathrm{Sr}^{2+}$, and $\mathrm{Pb}^{2+}$ on nitrogen, phosphorous, and potassium (NPK) uptake by plant were investigated using Taguchi approach.

\section{MATERIALS AND METHODS}

\section{Isolation of biosurfactant producing microorganisms}

Soil samples were collected from three different farms aged for 20, 40, and 60 years at El-Gabal ElAsfar area, Egypt as it listed in Table (1). Serial dilutions were carried out from rhizospheric zone and plated on nutrient agar media. After incubation period, the bacterial colonies were picked according to its dominance and variations. A total of fifteen colonies were isolated from nutrient agar and purified using successive streaking on nutrient agar media (Sanders, 2012).

\section{Screening of biosurfactant producing microorganisms}

The ability of isolates to produce biosurfactant was investigated according to oil spreading assay (Morikawa et al., 1993); blood hemolysis test (Sarvanan and Vijayakumar, 2012; Anandaraj and Thivakaran, 2010); blue agar plate (BAP) method (Sarvanan and Vijayakumar, 2012; Satpute et al., 2008); and emulsification test (Bodour et al., 2004).

\section{Separation of Biosurfactant}

Fungal isolate was grown on growth medium containing: $\quad \mathrm{NH}_{4} \mathrm{NO}_{3} \quad(1 \mathrm{~g} / \mathrm{L}), \quad \mathrm{KH}_{2} \mathrm{PO}_{4} \quad(0.2 \mathrm{~g} / \mathrm{L})$, $\mathrm{MgSO}_{4} \cdot 7 \mathrm{H}_{2} \mathrm{O}(0.2 \mathrm{~g} / \mathrm{L})$, glutamic acid $(10 \mathrm{~g} / \mathrm{L})$, and olive oil refinery residue $(60 \mathrm{~g} / \mathrm{L})$. After seven days of incubation period the culture broth was filtered through a Whatman filter paper (No. 1) and centrifuged at 5000 rpm for $20 \mathrm{~min}$. The cell free broth was concentrated by dry freezing then three volumes of chilled acetone were added and allowed to stand for $10 \mathrm{~h}$ at 4 ?C. The precipitate was collected by centrifuging and evaporating to dryness to remove the residual acetone and re-dissolved in the sterile water (Pruthi and Cameotra 1997).

\section{Identification of selected isolates}

\section{Morphological and microscopic identification}

The selected bacterial isolates were examined by using different morphological and biochemical tests, includes Gram staining, Motility test, Indole test, Methyl red test, Starch hydrolysis, Gelatin liquefaction test, Oxidase test, and Catalase test. The selected fungal isolates were identified based on the colony morphology, colony growth rate and microscopy features using standard taxonomic keys and monographs (Pitt and Hocking, 2009).

\section{Molecular characterization of selected bacterial isolates}

Genomic DNA of isolates was extracted directly from the colonies grown on solid medium and was used as template for PCR according to modified method of Ishikawa et al., (2000). The purified product was sequenced using (DYEynamic ET Terminator Cycle Sequencing Kit, Amersham Pharmacia Biotech. (ABI 3130) at Animal Health Institute, Agricultural Research Center, Cairo, Egypt.

\section{Phylogenetic analysis}

The 16S rRNA sequences of the isolates were assembled in BioEdit software (Hall, 1999). The nucleotide sequence was compared with similar sequences found in the NCBI database through BLAST program (NCBI website). Multiple nucleotide sequences alignment was performed using BioEdit and Clustal W. Neighbour joining phylogenetic tree was constructed using Phylip 3.65 (Felsenstein, 1993). The phylogenetic tree was constructed using the neighbor joining NJ method (Saitou and Nei 1987). The clustering stability of the tree was evaluated by bootstrap analysis of 100 data sets.

\section{Leaching experiments}

Leaching experiments were carried out using polyethylene tube of $6 \mathrm{~cm}$ in diameter and $20 \mathrm{~cm}$ length. The effective length of soil inside polyethylene columns was $10 \mathrm{~cm}$. Soil collected from El-Gabal El-Asfar area was placed inside polyethylene columns and artificially polluted with $\mathrm{Pb}^{2+}$ and $\mathrm{Sr}^{2+}$ at constant concentrations $150 \mathrm{mg} \mathrm{kg}^{-1}$ and $10 \mathrm{mg} \mathrm{kg}^{-1}$, respectively. The sources of $\mathrm{Pb}^{2+}$ and $\mathrm{Sr}^{2+}$ were $\mathrm{Pb}\left(\mathrm{NO}_{3}\right)_{2}$ and $\mathrm{SrCl}_{2} \cdot 6 \mathrm{H}_{2} \mathrm{O}$, respectively with analytical grade. The broth culture of the selected isolates and crude biosurfactant extract and their mixture were added separately to the polyethylene tube. The control experiment was treated with $10 \mathrm{ml}$ distilled water to keep soil wet during experimental period. Distilled water $(10 \mathrm{ml})$ was added to the soil column to keep soil wet during experiment period (15 days). The total concentration of $\mathrm{Pb}^{2+}$ and $\mathrm{Sr}^{2+}$ in outlet leachate was detected using Inductivity Coupled Argon 
Table 1. The locations of the different soils samples collected from El-Gabal El-Asfar

\begin{tabular}{|c|c|c|c|}
\hline \multirow{2}{*}{ No } & \multicolumn{2}{|c|}{ Locations } & \multirow{2}{*}{ Cultivation period } \\
\hline & Latitude & Longitude & \\
\hline 1 & $30 ' 13 \quad 11.6 \mathrm{~N}^{\mathrm{o}}$ & $31 ' 23 " 14.9 \mathrm{E}^{\mathrm{o}}$ & 60 years \\
\hline 2 & $30 ' 11 " 37.9 \mathrm{~N}^{\mathrm{o}}$ & $31 ' 23 " 2.6 \mathrm{E}^{\mathrm{o}}$ & 40 Years \\
\hline 3 & $30 ' 11 " 29.6 \mathrm{~N}^{\circ}$ & $31 ' 23 \quad 33.9 \mathrm{E}^{\mathrm{o}}$ & 20 Years \\
\hline
\end{tabular}

\begin{tabular}{lcc}
\hline \multicolumn{2}{c}{ Table 2. Physical and chemical properties of the main soil (aged for 60 years) } \\
\hline \multicolumn{2}{c}{ Soil Properties } & El-Gabal El-Asfer area \\
\hline Soil Texture & Sand $\%$ & Loamy sand \\
& Silt $\%$ & 81.1 \\
Particle size distribution & Clay\% & 7.6 \\
& & 11.3 \\
Total $\mathrm{CaCO}_{3}(\%)$ & 8.3 \\
$\mathrm{OM}(\%)$ & 4.31 \\
$\mathrm{CEC}\left(\mathrm{meq}^{\left.100 \mathrm{~g}^{-1}\right)}\right.$ & 23.9 \\
$\mathrm{pH}(1: 2.5)$ & 7.72 \\
$\mathrm{EC}\left(\mathrm{dS} \mathrm{m}{ }^{-1}\right)$ & 3.98 (Saline Soil) \\
\hline
\end{tabular}

Table 3. Orthogonal array $\left(\mathrm{L}_{16} \mathrm{OA}\right)$ shows the studied factors and their levels

\begin{tabular}{cccc}
\hline Trials & $\begin{array}{c}\text { Biosurfactant producing } \\
\text { microorganisms }\end{array}$ & $\mathrm{Sr}^{2+}\left(\mathrm{mg} \mathrm{kg}^{-1}\right)$ & $\mathrm{Pb}^{2+}\left(\mathrm{mg} \mathrm{kg}^{-1}\right)$ \\
\hline 1 & Without & 0 & 0 \\
2 & $\mathrm{~A}^{*}$ & 3 & 50 \\
3 & $\mathrm{~A}$ & 5 & 100 \\
4 & $\mathrm{~A}$ & 10 & 150 \\
5 & Without & 0 & 50 \\
6 & $\mathrm{~B} * *$ & 3 & 0 \\
7 & $\mathrm{~B}$ & 5 & 150 \\
8 & $\mathrm{~B}$ & 10 & 100 \\
9 & Without & 0 & 100 \\
10 & $\mathrm{C} * * *$ & 3 & 150 \\
11 & $\mathrm{C}$ & 5 & 0 \\
12 & $\mathrm{C}$ & 10 & 50 \\
13 & Without & 0 & 150 \\
14 & $\mathrm{~A}+\mathrm{B}+\mathrm{C}$ & 3 & 50 \\
15 & $\mathrm{~A}+\mathrm{B}+\mathrm{C}$ & 5 & 0 \\
16 & $\mathrm{~A}+\mathrm{B}+\mathrm{C}$ & 10 & \\
\hline
\end{tabular}

*P. lubricantisa

** L. novalis

*** Crude biosurfactant extracted from A. niger

Plasma (ICAP 6500 Duo, Thermo Scientific England).

The physical and chemical properties of the studied soils are listed in Table (2) according to (Jackson, M. L. 1973).

\section{Taguchi approach experiments}

In this experimental work, the experiential design was carried out using Taguchi approach $\left(\mathrm{L}_{16} \mathrm{OA}\right)$, in which three factors at five and four levels were studied.

Watercress (Eruca vesicaria subsp. Sativa) was grown for 45day in pots, in which each pot was filled with I kg soil. The first factor was biosurfactant producing microorganisms (without additions, Pseudochrobactrum lubricantisa (A), Lysobacter novalis (B), and crude biosurfactant extracted from Aspergillus niger (C), and mixed addation $(\mathrm{A}+\mathrm{B}+\mathrm{C})$. The second factor was $\mathrm{Sr}^{2+}$ doses $\left(0,3,5\right.$, and $\left.10 \mathrm{mg} \mathrm{kg}^{-1}\right)$. The third factor was 
$\mathrm{Pb}^{2+}$ doses $\left(0,50,100\right.$, and $\left.150 \mathrm{mg} \mathrm{kg}^{-1}\right)$. More details about Taguchi approach may be found in the following studies (Abou-Shady and Peng, 2012; Jin et al., 2012; Abou-Shady et al., 2012a, Abou-Shady et al., 2016b). The sixteen trials and the studied factors and there levels, are presented in Table (3). The sequential extraction of $\mathrm{Pb}^{2+}$ was determined according to (Tessier et al., 1979). The calculation of $\mathrm{S} / \mathrm{N}$ (signal-to-noise) ratio was carried out based on the optimized values derived from (the larger-the better) according to the following equation:

The larger-the better (MSD) = -10 $\log _{10}\left(\frac{1}{n} \sum_{j=1}^{n} \frac{1}{S P_{j}^{2}}\right)$

where MSD is the mean square deviation, $\mathrm{n}$ is the number of observations, and $\mathrm{SP}_{\mathrm{j}}^{2}$ is the experimental response (Abou-Shady et al., 2012a).

The experimental responses that illustrated the effects of biosurfactant producing bacteria, $\mathrm{Sr}^{2+}$ doses, and $\mathrm{Pb}^{2+}$ doses on different forms of $\mathrm{Pb}^{2+}$ and the NPK uptake by plant were calculated according to the following equations:

The variation of $\mathrm{Pb}^{2+}$

$(\%)=\frac{\text { The detected value of different form of } \mathrm{Pb}^{2+}}{\text { Total concentration of } \mathrm{Pb}^{2+} \text { in each trial }} * 100$

The variation of NPK $(\%)$ uptake by plant (watercress)=

$\underline{\text { (Total concentration of (NPK) in blank experiment - The detected value of (NPK) in each trial) }} * 100$

Total concentration of (NPK) in blank experiment

RESULTS AND DISCUSSION

Screening for biosurfactant substances

Table 4. Screening of biosurfactant producing microorganisms

\begin{tabular}{ccccc}
\hline Isolate No. & Blood hemolysis & Displacement zone $(\mathrm{mm})$ & Methylene blue agar plate & E24 \\
\hline GA1 & $\beta$ hemolysis & 3.0 & positive & 57.1 \\
GA2 & $\alpha$-hemolysis & 2.0 & negative & 42.9 \\
GA3 & $\beta$ hemolysis & 3.0 & positive & 66.7 \\
GA4 & $\beta$ hemolysis & 3.0 & positive & 60.0 \\
GA5 & $\alpha$-hemolysis & 3.0 & negative & 66.7 \\
GA6 & $\alpha$-hemolysis & 3.0 & negative & 66.7 \\
GA7 & $\beta$ hemolysis & 4.0 & positive & 66.7 \\
GA8 & $\beta$ hemolysis & 3.0 & positive & 50.0 \\
GA9 & $\beta$ hemolysis & 9.0 & positive & 85.0 \\
GA10 & $\beta$ hemolysis & 7.0 & positive & 80.0 \\
GA11 & $\beta$ hemolysis & 3.0 & positive & 56.7 \\
GA12 & $\alpha$-hemolysis & 2.0 & positive & 52.0 \\
GA13 & $\alpha$-hemolysis & 3.0 & negative & 60.0 \\
GA14 & $\beta$ hemolysis & negative & 72.0 \\
GA15 & $\beta$ hemolysis & 7.0 & positive & 84.0 \\
\hline
\end{tabular}

Fifteen morphologically distinct microbial colonies were isolated from three different farms aged for 20, 40, and 60 years at El-Gabal El-Asfar area, Egypt, and screened for the most effective biosurfactant producing isolate. The activity of microbial colonies to produce biosurfactant were determined using different methods namely oil spreading assay, blood hemolysis test, blue agar test, and emulsification activity as it listed in Table 4. Oil spreading method represent an easy and sensitive method that can be used to test the production of biosurfactant. This technique measures the diameter of displacement caused when a drop of a biosurfactant containing solution is placed on an oil water surface (Morikawa et al., 2000). The ability of isolates to lyses the erythrocytes when it grown on blood agar media indicated the production of biosurfactant. The hemolytic activity of biosurfactant was first discovered by (Bernheimer and Avigad, 1970). Blood agar lysis has been used to quantify surfactant (Moran et al., 200) and rhamnolipids (Johnson and Boese-Marrazzo, 1980). Dark blue halo zone appeared around the isolated colonies in the methylene blue agar plate confirmed the presence of an anionic biosurfactant. This colorimetric assay based on the formation of insoluble ion pair between anionic surfactants, cationic cetyl trimethyl ammonium bromide (CTAB), and methylene blue (Siegmund and Wagner, 1991). Emulsification test represents a quantitative method to assay the potency of isolates to produce biosurfactant. The isolated bacteria were tested for their abilities to emulsify crude oil by adding $2 \mathrm{ml}$ of olive oil to $2 \mathrm{ml}$ of culture supernatant and kept overnight. The emulsification activities were calculated in terms of percentage as it shown in Table (4). 
The results showed that the isolates namely GA9, GA10 and GA15 gave the maximum emulsification activity $(85,80$, and $84 \%)$ and the highest displacement zone of oil $(9,7$, and $7 \mathrm{~mm})$, respectively. Thus they were chosen for further studies.

\section{Identification and phylogenetic analysis}

The morphological and biochemical characters of selected bacterial isolates are presented in Table (5). Isolate GA15 is a Gram negative, aerobic, rod-shaped, motile and had peige color and the $16 \mathrm{~S}$ rRNA nucleotide sequence revealed that it belongs to $L$. novalis with $96 \%$ blast identity, while isolate GA9 is Gram negative bacillus or short rods, the colonies were creamy. The $16 \mathrm{~S}$ rRNA nucleotide sequence revealed that it belonged to $P$. lubricantisa with $95 \%$ blast identity. Phylogenetic tree of the two bacterial strains and closely related strains indicated the grouping of isolate GA9 with $P$. lubricantisa with bootstrap value of $53 \%$ and GA15 was grouped with L. novalis with $100 \%$ bootstrap value as it illustrated in Figs. (1 and 2).

Table. 5. The morphological and biochemical characters of selected bacterial isolates

\begin{tabular}{lll}
\hline \multicolumn{1}{c}{ Characteristics } & \multicolumn{1}{c}{ GA9 } & GA15 \\
\cline { 2 - 3 } Gram staining & -ve & -ve \\
shape & Rod & Rod \\
Motility test & Non-motile & motile \\
Spore forming & Non-spore forming & Non-spore forming \\
Indole test & $+\mathrm{ve}$ & $+\mathrm{ve}$ \\
Methyl red test & $-\mathrm{ve}$ & $-\mathrm{ve}$ \\
Starch hydrolysis & $+\mathrm{ve}$ & $+\mathrm{ve}$ \\
Gelatin liquefaction test & $+\mathrm{ve}$ & $+\mathrm{ve}$ \\
Oxidase test & $+\mathrm{ve}$ & $+\mathrm{ve}$ \\
Catalase test & $+\mathrm{ve}$ & $+\mathrm{ve}$ \\
\hline
\end{tabular}

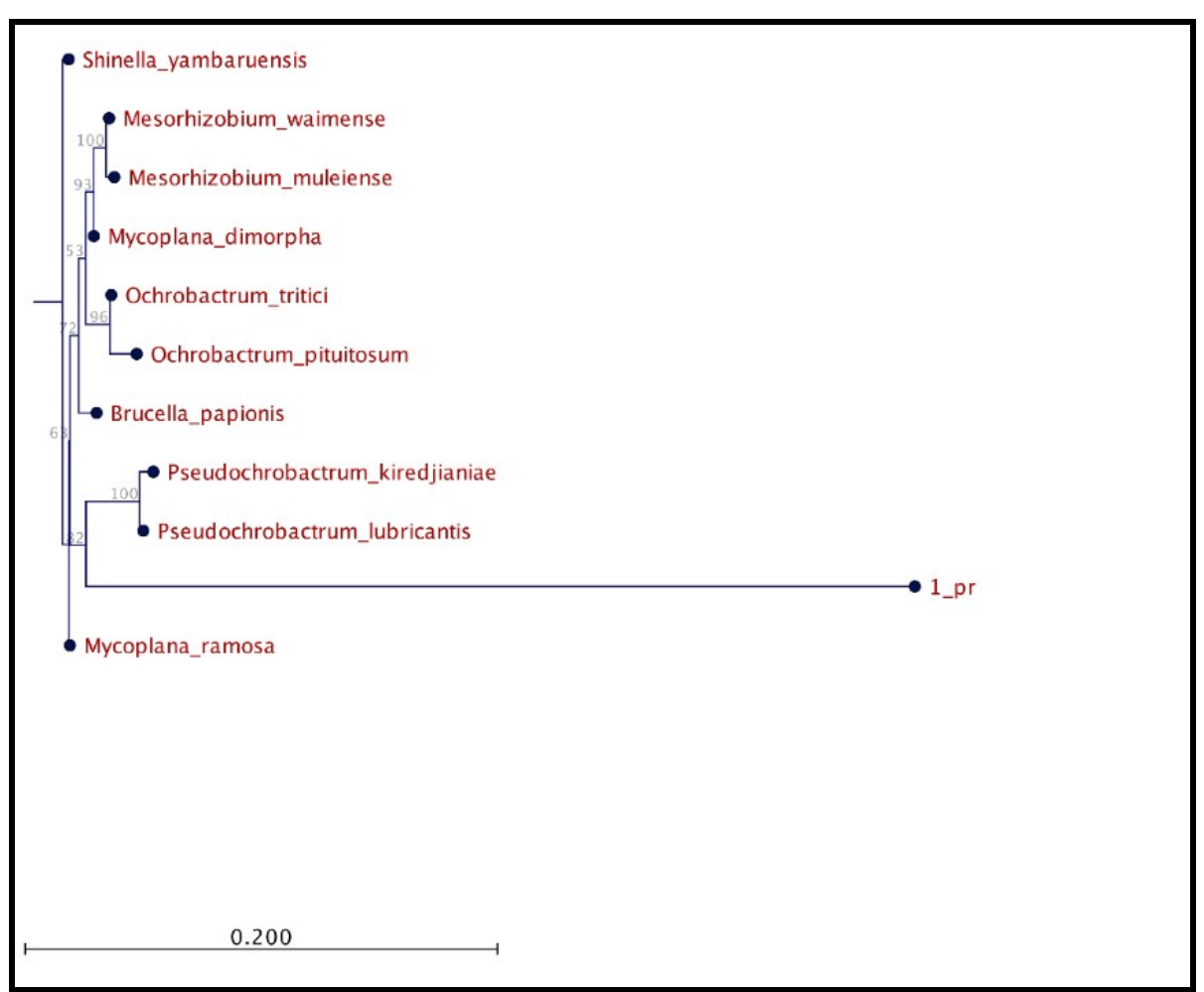

Fig. 1. Neighbor joining phylogenetic tree of partial 16S rRNA sequence of isolates GA9. The scale bar represents $10 \%$ nucleotide substitutions. Percentages of bootstrap values recovered from 100 trees are presented on the nodes 


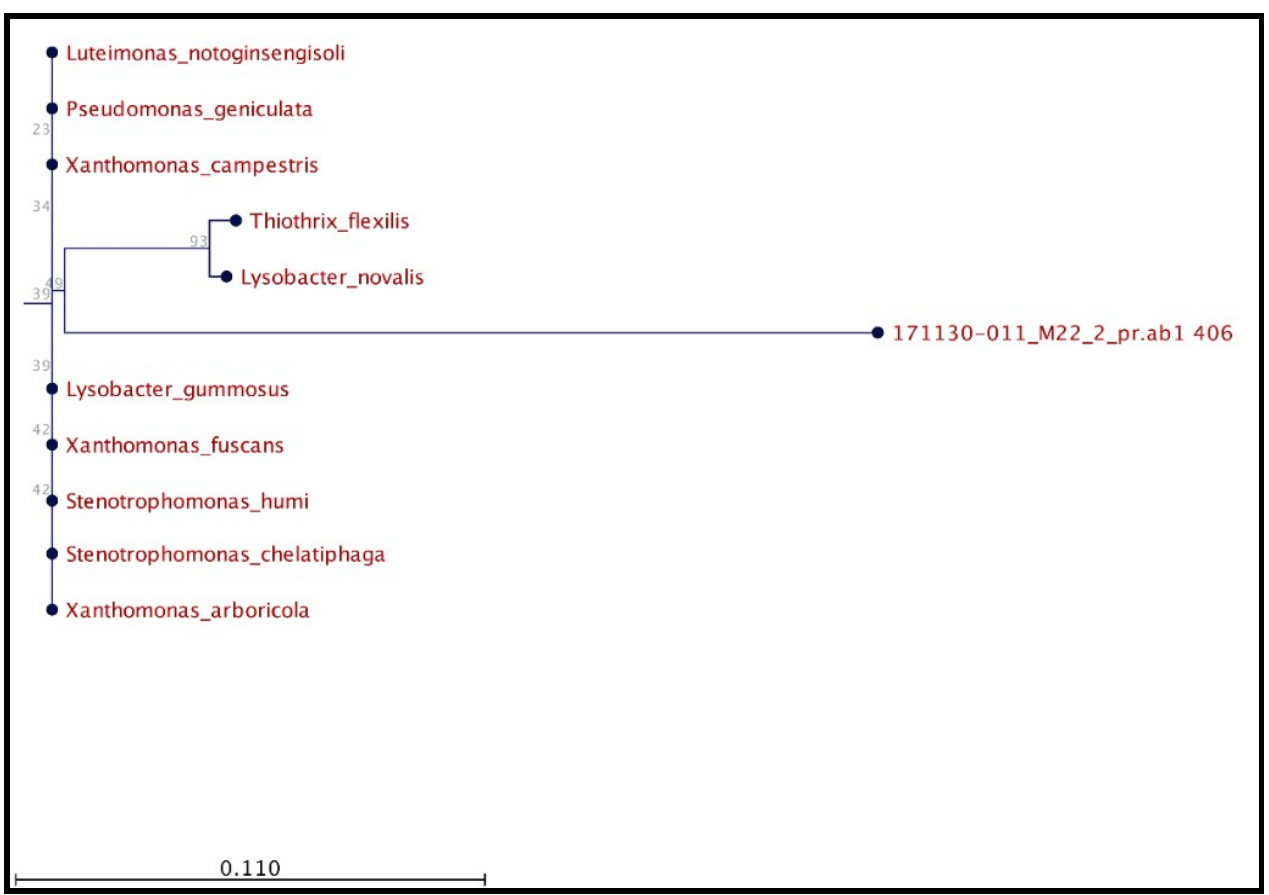

Fig. 2. Neighbor joining phylogenetic tree of partial 16S rRNA sequence of isolates GA15. The scale bar represents $10 \%$ nucleotide substitutions. Percentages of bootstrap values recovered from 100 trees are presented on the nodes

The fungal isolate GA10 was found to belong to $A$. niger. It showed fast growing black colonies on Czapek Dox agar medium. Surface is charcoal black, granular, flat and reverse side is colorless to white. Microscopic characters of fungal isolate were investigated under light microscope. The conidiophores are long, smooth, colorless or brown and vesicle is large and round.

\section{Leaching experiments}

The main goal of this part was to choose the appropriate pollutant in which biosurfactant producing bacteria may decrease it availability in soil. Afterward, Taguchi approach will be used to preciously identify the effects of different parameters. The effects of isolated bacteria on the leaching of artificially polluted soils with $\mathrm{Pb}^{2+}$ and $\mathrm{Sr}^{2+}$ at constant concentrations of $150 \mathrm{mg}$ $\mathrm{kg}^{-1}$ and $10 \mathrm{mg} \mathrm{kg}^{-1}$ were studied as it shown in Figs. (3 and 4). Fig. (3) shows the increased and decreased percent of $\mathrm{Pb}^{2+}$ and $\mathrm{Sr}^{2+}$ compared with the out let leachate of the untreated soils.

The application of biosurfactant producing bacteria significantly decreased the mobility of $\mathrm{Pb}^{2+}$ in the polluted soil and in contrast increased $\mathrm{Sr}^{2+}$ concentrations in the outlet leachate. The most effective bacteria that increased the precipitation/ adsorption of $\mathrm{Pb}^{2+}$ was $L$. novalis bacteria in which the reduction in $\mathrm{Pb}^{2+}$ concentration reached to $>69 \%$ compared with untreated soil. The order of biosurfactant producing bacteria that decreased the availability of $\mathrm{Pb}^{2+}$ in polluted soils took the following sequence $P$. lubricantis bacteria (B) $>$ the mixture addition of $(\mathrm{A}+\mathrm{B}+\mathrm{C})>$ L. novalis bacteria $(\mathrm{A})>A$. niger (crude biosurfactant) (C). When three species of bio-treatment mixed $(\mathrm{A}+\mathrm{B}+\mathrm{C})$ together the response of $\mathrm{Pb}^{2+}$ in the treaded soil took the same tendency observed with $L$. novalis bacteria (B). Accordingly, Biosurfactant producing bacteria may be used as immobilize material to decrease plant uptake of $\mathrm{Pb}^{2+}$ in El-Gabal El-Asfar area. Hogan et al., reported that $\mathrm{Pb}^{2+}$ strongly bonded with biosurfactant compared with moderate bond that was obtained with other rare elements such as $\mathrm{Ca}^{2+}$ and $\mathrm{Cd}^{2+}$, and weak bond with $\mathrm{Sr}^{2+}, \mathrm{Ni}^{2+}$, and $\mathrm{Mn}^{2+}$. The biosurfactant may be adsorbed strongly with $\mathrm{Pb}^{2+}$ simultaneously with soil particles. So, that in our experiment $\mathrm{Pb}^{2+}$ did not leached out compared with $\mathrm{Sr}^{2+}$. Hong et al., 1997 studied the removal percent of $\mathrm{Cd}^{2+}$ and $\mathrm{Pb}^{2+}$ using aescin as a biosurfactant and reported that the carboxylic and saccharide moieties had the main role to isolate these elements during soil washing.

Fig. (4) presents the effect of biosurfactant producing bacteria on $\mathrm{Sr}^{2+}$ mobility in the treated soils. The results indicated that, $\mathrm{Sr}^{2+}$ levels significantly increased in the outlet leachate with very high percent reached to $803 \%$ (8 fold from $\mathrm{Sr}^{2+}$ concentration obtained with the untreated leachate) when $P$. lubricantis bacteria (A) was added to the treated soil.

The impacts of either L. novalis bacteria (B) or $A$. niger (crude biosurfactant) (C) were almost the same 
about $580 \%$ (5.8 fold from $\mathrm{Sr}^{2+}$ concentration obtained with the untreated leachate) as it depicted in Fig. (4). Blending the three P. lubricantis bacteria (A), L. novalis bacteria (B), and A. niger (crude biosurfactant) (C) together increased the concentrations of $\mathrm{Sr}^{2+}$ in the outlet leachate higher than L. novalis bacteria (B) and $A$.

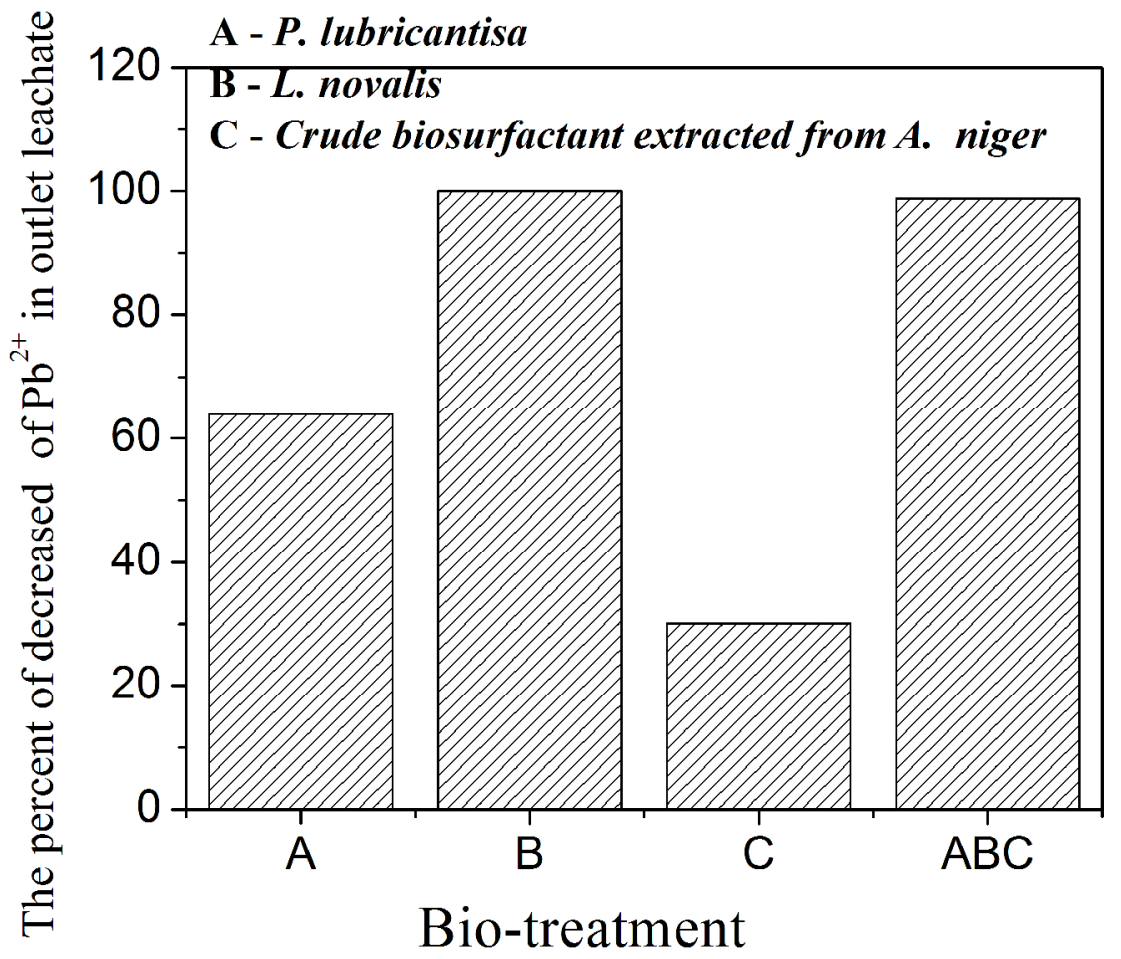

Fig. 3. The variation of outlet $\mathbf{P b}^{2+}$ containing leachate compared with blank experiments

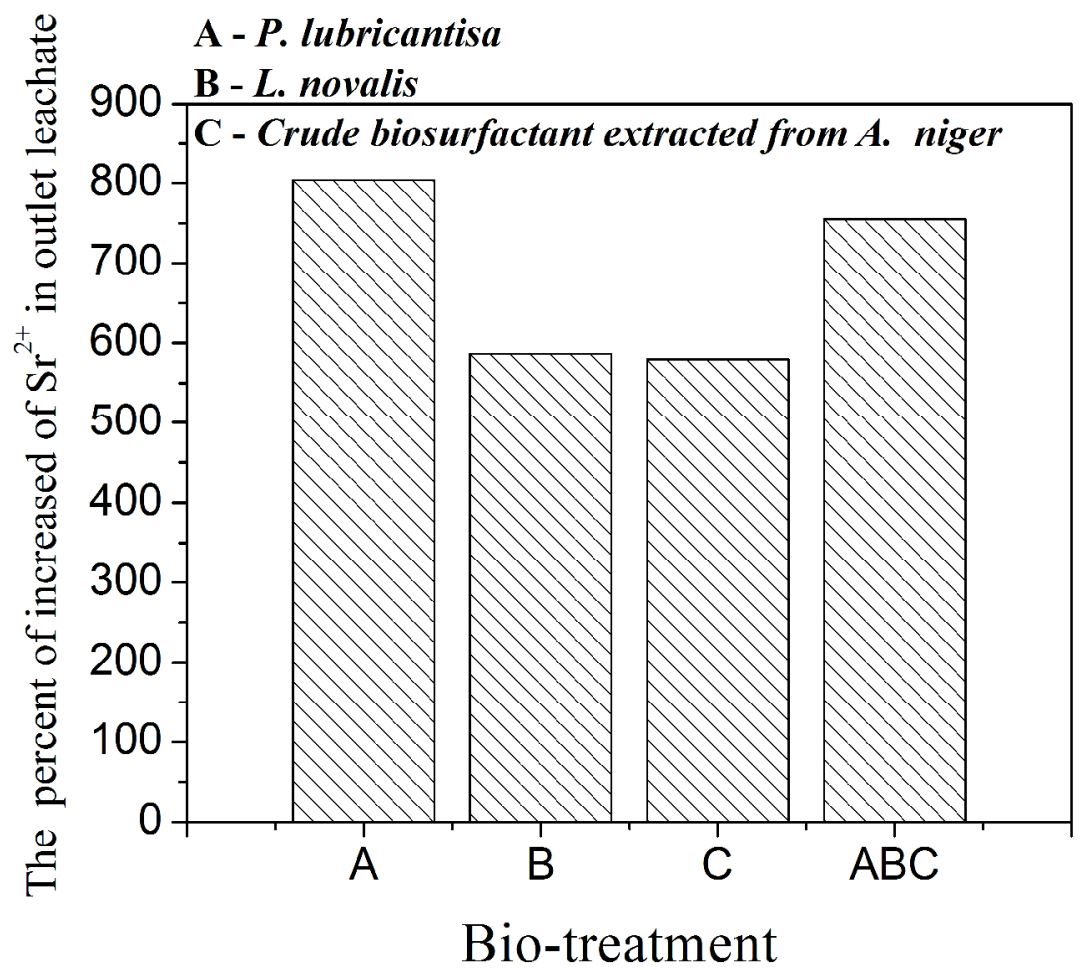

Fig. 4. The variation of outlet $\mathrm{Sr}^{2+}$ containing leachate compared with blank experiments 
niger (crude biosurfactant) $(\mathrm{C})$, but less than $P$. lubricantis bacteria (A). According to data observed from column leaching experiments, $\mathrm{Pb}^{2+}$ was chosen as the most alternative polluted element to study the effect of biosurfactant producing bacteria of $\mathrm{Pb}^{2+}$ uptake by plant using Taguchi approach.

\section{Taguchi approach experiments}

Taguchi approach $\left(\mathrm{L}_{16} \mathrm{OA}\right)$ was utilized in which 16 trials were carried out in lab pots. The experiment response and it signal to noise ratio $(\mathrm{S} / \mathrm{N})$ are presented in Table (6). Figure. (5) shows the effect of biosurfactant producing bacteria on the variation of $\mathrm{Pb}^{2+}$ species in the treated soils, and the results are opposite with that obtained in the leaching experiments Fig. (3). The contradictory of results observed in the leaching experiment and Taguchi approach may be owing to that in Taguchi approach $\mathrm{Pb}^{2+}$ behaviors were studied based on different $\mathrm{Pb}^{2+}$ forms derived from sequential extraction.

L. novalis bacteria (B) and A. niger (crude biosurfactant) $(\mathrm{C})$, and mixed addition $(\mathrm{A}+\mathrm{B}+\mathrm{C})$ did not show any noticeable effect on the reduction of available $\mathrm{Pb}^{2+}$. L. novalis bacteria (B) showed the best results to decrease the exchangeable form of $\mathrm{Pb}^{2+}$ compared with other species of bacteria. The addition of mixture addition $(\mathrm{A}+\mathrm{B}+\mathrm{C})$ presented an increment of sulfate form of $\mathrm{Pb}^{2+}$ compared with the sole addition of bacteria. A. niger (crude biosurfactant) (C) increased the carbonate bonded to $\mathrm{Pb}^{2+} . \mathrm{Pb}^{2+}$ existed in organic forms was influenced with the addition of mixture addition
$(\mathrm{A}+\mathrm{B}+\mathrm{C})$. The addition of $A$. niger (crude biosurfactant) (C) and blank experiments showed a stable concentrations of $\mathrm{Pb}^{2+}$ content in plant.

The addition of P. lubricantis (A) and L. novalis (B) resulted in an increment of $\mathrm{Pb}^{2+}$ content in plant as it presented in Fig. (5).

Fig. (6) shows the effects of $\mathrm{Sr}^{2+}$ doses on different forms of $\mathrm{Pb}^{2+}$ simultaneously with the addition of biosurfactant producing bacteria. The available $\mathrm{Pb}^{2+}$ oscillated with the addition of $\mathrm{Sr}^{2+}$. In the blank experiment, the available $\mathrm{Pb}^{2+}$ was found with comparatively high concentrations more that found when $\mathrm{Sr}^{2+}$ doses were added. On the other hand, increasing $\mathrm{Sr}^{2+}$ concentrations decreased the content of exchangeable $\mathrm{Pb}^{2+}$, however at high concentrations of $150 \mathrm{mg} \mathrm{kg}^{-1}$ the exchangeable content was increased again to be close to that found in the blank experiment. The carbonated content of $\mathrm{Pb}^{2+}$ did not influence with either low or high concentrations of $\operatorname{Sr}^{2+}(0,3$, and 10 $\left.\mathrm{mg} \mathrm{kg}^{-1}\right)$. It's clear seeing that, the medium concentration of $\mathrm{Sr}^{2+}$ increased $\mathrm{Pb}^{2+}$ carbonated content of. $\mathrm{Pb}^{2+}$ bonded to sulfate did not influence with the low concentration of $\mathrm{Sr}^{2+}$, however at high concentrations it was found that, $\mathrm{Pb}^{2+}$ bonded to sulfate was increased noticeably. $\mathrm{Pb}^{2+}$ bonded to organic compounds was greatly affected with the low concentrations of $\mathrm{Sr}^{2+}\left(3 \mathrm{mg} \mathrm{kg} \mathrm{kg}^{-1}\right)$, the rest of concentration did not show any noticeable effect. Total concentration of $\mathrm{Pb}^{2+}$ in plant increased with increasing $\mathrm{Sr}^{2+}$ doses.

Table 6. The variations of different forms of $\mathrm{Pb}^{2+}(\%)$ and its calculated $(\mathrm{S} / \mathrm{N})$ in the treated soil

\begin{tabular}{ccccccccccccc}
\hline \multicolumn{2}{c}{ Available } & \multicolumn{2}{c}{ Exchangeable } & \multicolumn{2}{c}{ Carbonate bond } & \multicolumn{2}{c}{ Sulfate bond } & \multicolumn{2}{c}{ Organic bond } & \multicolumn{2}{c}{ Plant } \\
\hline $\mathrm{Pb}^{2+}$ & $\mathrm{S} / \mathrm{N}$ & $\mathrm{Pb}^{2+}$ & $\mathrm{S} / \mathrm{N}$ & $\mathrm{Pb}^{2+}$ & $\mathrm{S} / \mathrm{N}$ & $\mathrm{Pb}^{2+}$ & $\mathrm{S} / \mathrm{N}$ & $\mathrm{Pb}^{2+}$ & $\begin{array}{c}\mathrm{S} / \mathrm{N} \\
(\%)\end{array}$ & $\begin{array}{c}\mathrm{Pb}^{2+} \\
(\%)\end{array}$ & $\begin{array}{c}\mathrm{S} / \mathrm{N} \\
\text { ratio }\end{array}$ \\
\hline 257.98 & ratio & $(\%)$ & ratio & $(\%)$ & ratio & $(\%)$ & ratio & $(\%)$ & ratio & 15.16 & 23.61 \\
24.99 & 48.23 & 1.98 & 5.95 & 4.70 & 13.45 & 4.12 & 12.30 & 21.89 & 26.80 & 15.16 & \\
31.38 & 27.95 & 0.0006 & -64.30 & 0.64 & -3.89 & 1.41 & 2.97 & 0.03 & -30.99 & 73.52 & 37.33 \\
0.53 & -5.54 & 0.59 & -4.54 & 4.67 & 13.39 & 3.86 & 11.73 & 3.36 & 10.52 & 76.47 & 37.67 \\
39.57 & 31.95 & 0.0012 & -58.06 & 0.53 & -5.49 & 2.65 & 8.46 & 3.96 & 11.94 & 60.31 & 35.61 \\
30.00 & 29.54 & 0.0015 & -56.76 & 0.45 & -6.92 & 1.86 & 5.40 & 2.44 & 7.74 & 82.64 & 38.34 \\
23.75 & 27.51 & 0.0012 & -58.65 & 0.47 & -6.50 & 1.96 & 5.84 & 0.84 & -1.55 & 52.38 & 34.38 \\
39.28 & 31.88 & 0.21 & -13.59 & 0.00 & -63.45 & 1.11 & 0.92 & 1.33 & 2.45 & 47.57 & 33.55 \\
57.19 & 35.15 & 0.20 & -14.11 & 0.0009 & -61.21 & 2.67 & 8.52 & 2.54 & 8.10 & 11.36 & 21.11 \\
38.19 & 31.64 & 0.12 & -18.61 & 0.0014 & -57.38 & 1.85 & 5.35 & 1.49 & 3.44 & 13.26 & 22.45 \\
53.13 & 34.51 & 0.0042 & -47.59 & 0.74 & -2.62 & 7.29 & 17.25 & 6.76 & 16.59 & 84.83 & 38.57 \\
44.56 & 32.98 & 0.29 & -10.62 & 0.00 & -54.88 & 2.17 & 6.73 & 2.69 & 8.58 & 28.87 & 29.21 \\
29.06 & 29.26 & 0.23 & -12.66 & 2.12 & 6.52 & 1.42 & 3.05 & 1.51 & 3.58 & 33.91 & 30.61 \\
8.05 & 18.12 & 0.28 & -11.10 & 1.65 & 4.34 & 2.56 & 8.16 & 0.00 & -58.07 & 53.21 & 34.52 \\
24.43 & 27.76 & 0.01 & -43.87 & 1.49 & 3.48 & 3.29 & 10.34 & 2.00 & 6.03 & 59.31 & 35.46 \\
269.70 & 48.62 & 0.03 & -31.84 & 6.87 & 16.74 & 47.35 & 33.51 & 32.60 & 30.26 & 59.75 & 35.53 \\
\hline
\end{tabular}




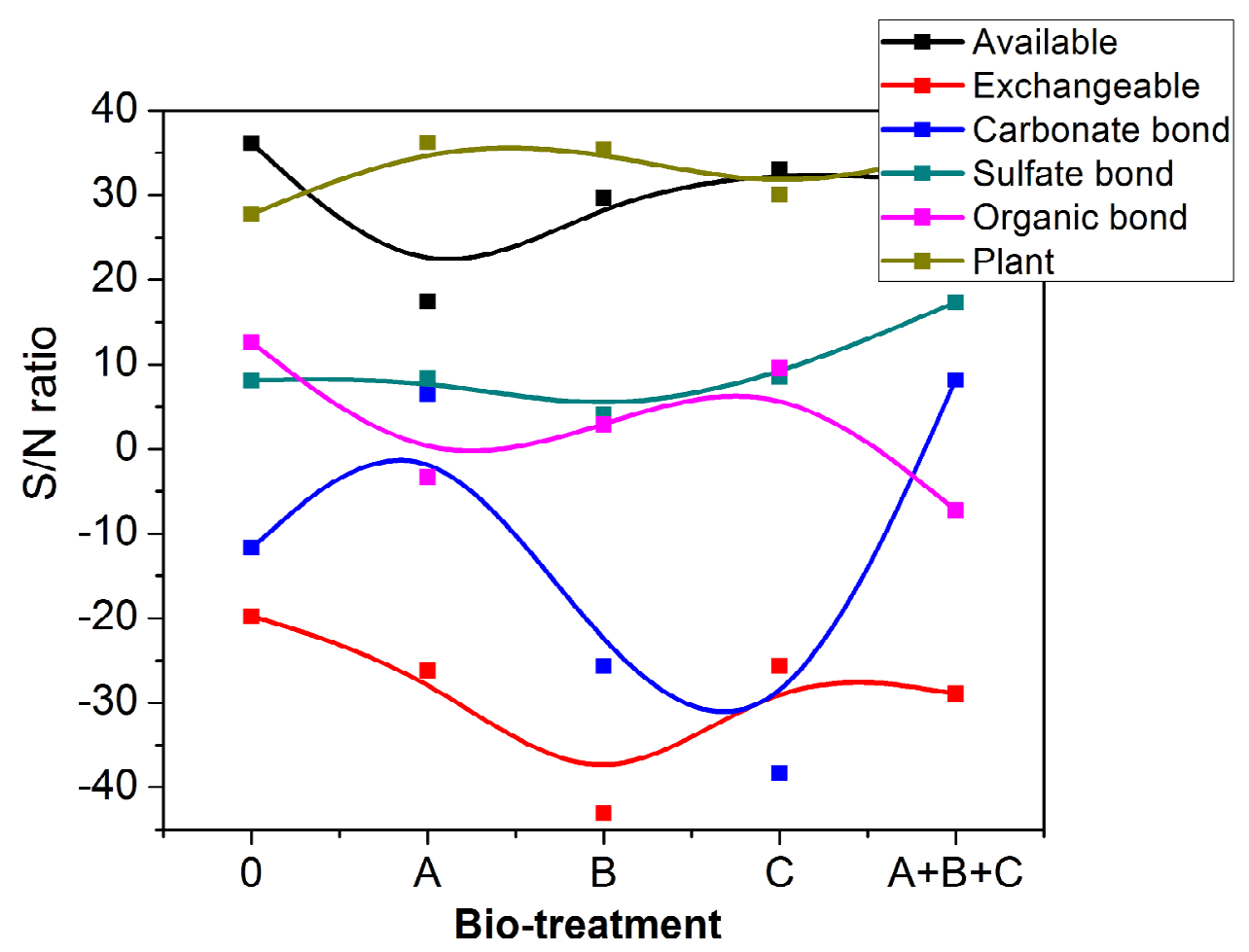

Fig. 5. Effect of biosurfactant producing bacteria on the variation of $\mathrm{Pb}^{2+}$ species in the treated soils $(\mathrm{S} / \mathrm{N}$ is signal to noise ratio)

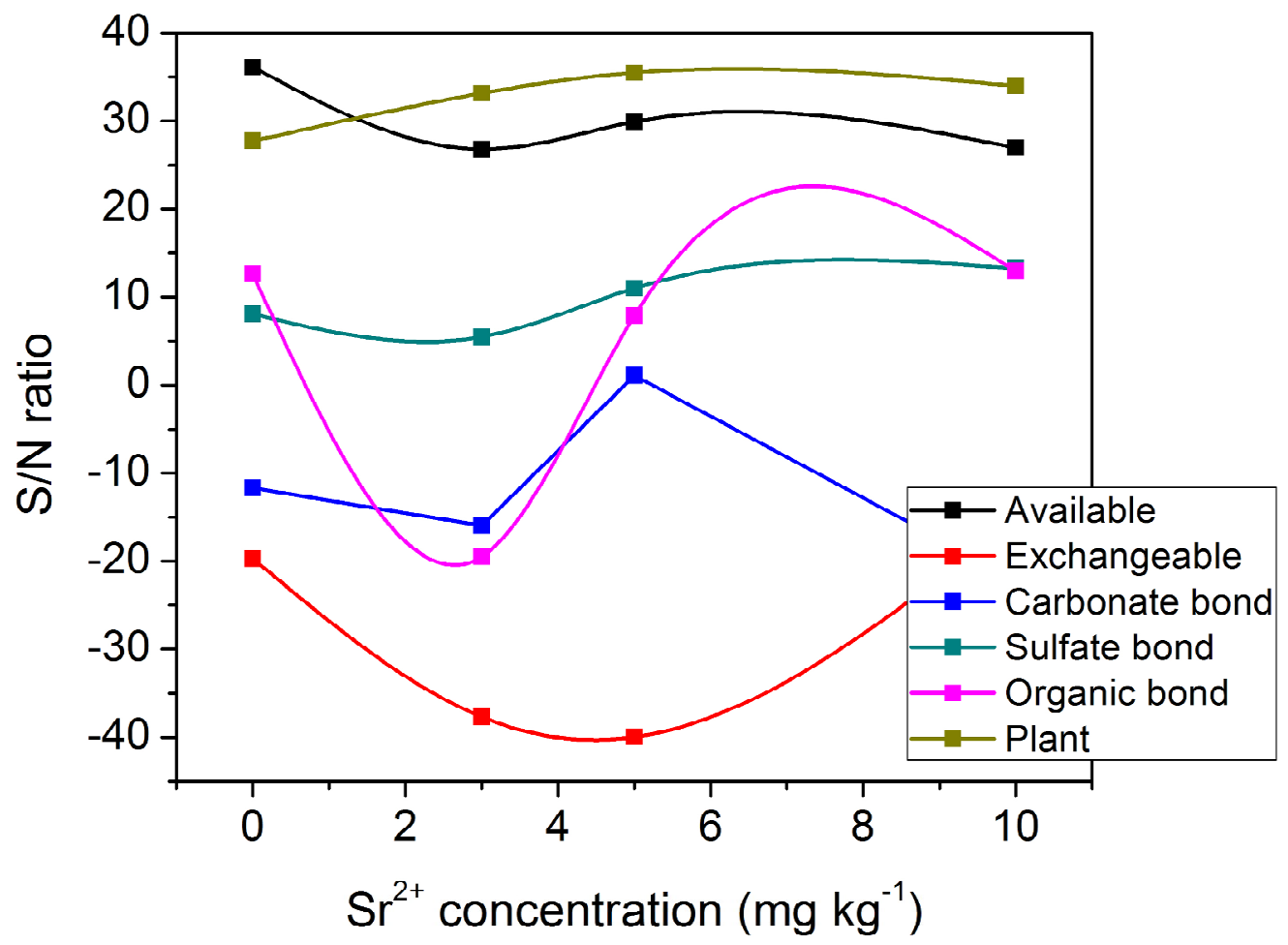

Fig. 6. Effect of $\mathrm{Sr}^{2+}$ doses on the variation of $\mathrm{Pb}^{2+}$ species in the treated soils ( $\mathrm{S} / \mathrm{N}$ is signal to noise ratio) 


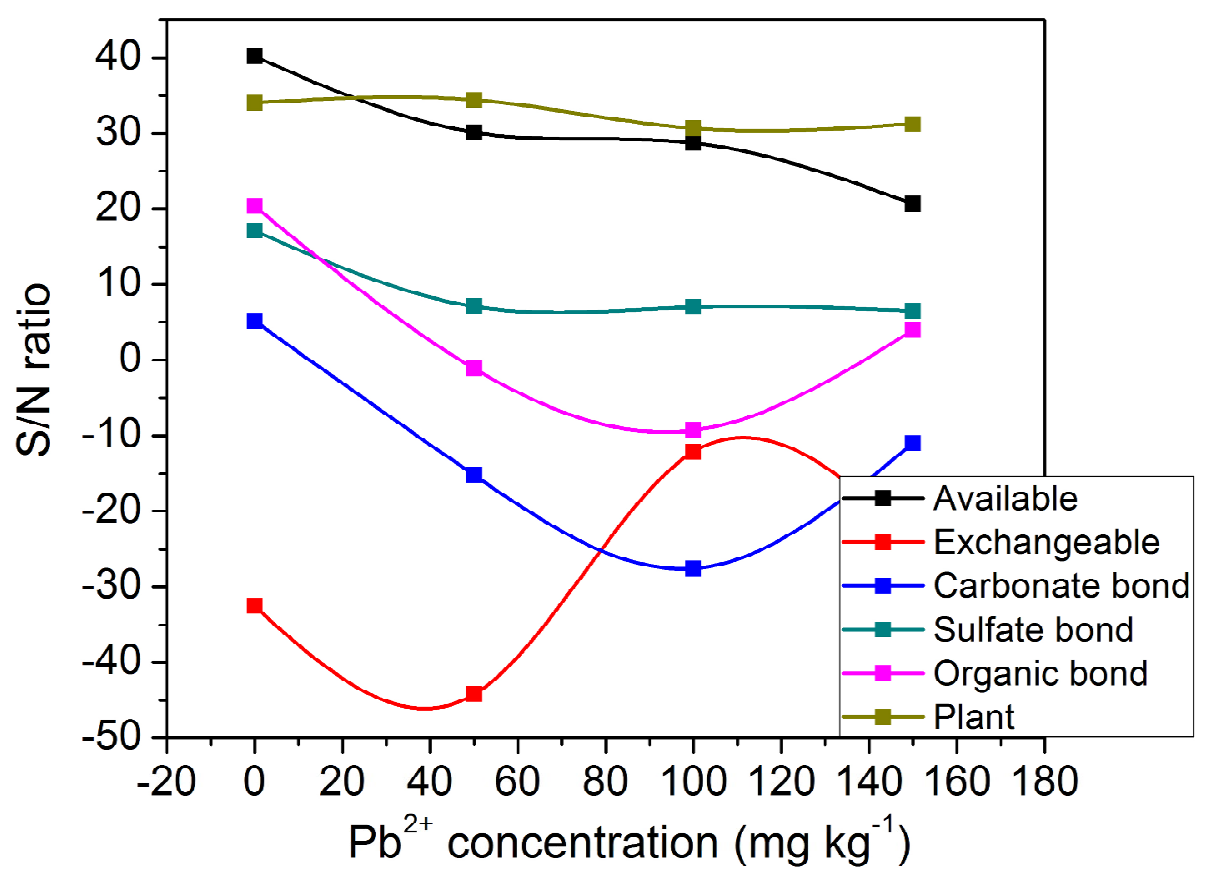

Fig. 7. Effect of $\mathbf{P b}^{2+}$ doses on the variation of $\mathrm{Pb}^{2+}$ species in the treated soils ( $\mathrm{S} / \mathrm{N}$ is signal to noise ratio)

The effects of $\mathrm{Pb}^{2+}$ concentrations on variations of different forms are presented in Fig. (7). Increasing the addition of $\mathrm{Pb}^{2+}$ decreased the percentage of available form in the treated soil. This is may be due to great immobilization impact of biosurfactant producing bacteria. However, the exchangeable forms of $\mathrm{Pb}^{2+}$ were quite high at $\mathrm{Pb}^{2+}$ concentrations (100) $\mathrm{mg} \mathrm{kg}^{-1}$. Addition of $\mathrm{Pb}^{2+}$ with low concentration of $50 \mathrm{mg} \mathrm{kg}^{-1}$ or high concentrations of $150 \mathrm{mg} \mathrm{kg}^{-1}$ did not increase the concentrations of $\mathrm{Pb}^{2+}$ in exchangeable form. $\mathrm{Pb}^{2+}$ bonded to carbonate was decreased when $\mathrm{Pb}^{2+}$ doses were added at concentration of 50 and $100 \mathrm{mg} \mathrm{kg}^{-1}$. On the other hand, the higher concentrations of $\mathrm{Pb}^{2+}(150$ mg kg${ }^{-1}$ ) increased again $\mathrm{Pb}^{2+}$ carbonate content.

$\mathrm{Pb}^{2+}$ bonded to sulfate was quite high with the blank experiment. $\mathrm{Pb}^{2+}$ bonded to sulfate did not influence with different concentration varied from 50 to $150 \mathrm{mg}$ $\mathrm{kg}^{-1} . \mathrm{Pb}^{2+}$ existed in organic forms were almost the same at concentrations of 50 and $150 \mathrm{mg} \mathrm{kg}^{-1}$, however at concentration equal to $100 \mathrm{mg} \mathrm{kg}^{-1}$ the formation of $\mathrm{Pb}^{2+}$

bonded to organic was noticeability decreased. The highest values of $\mathrm{Pb}^{2+}$ bonded to organic form was observed with the naturally exited concentration. Finally, plant uptake of $\mathrm{Pb}^{2+}$ did not influence with the wide range of $\mathrm{Pb}^{2+}$ concentrations. $\mathrm{Pb}^{2+}$ concentrations in the outlet leachate in the 16 trials did not detect using Atomic Absorption Spectrophotometer.

Figure. (8) shows that, the most affected factors influenced the available form of $\mathrm{Pb}^{2+}$ in studied trials were $\mathrm{Pb}^{2+}$ doses > biosurfactant producing bacteria > $\mathrm{Sr}^{2+}$ doses, however for exchangeable form the most influenced factors took the following order biosurfactant producing bacteria $>\mathrm{Sr}^{2+}$ doses $>\mathrm{Pb}^{2+}$ doses. $\mathrm{Pb}^{2+}$ bonded to carbonate was influenced with biosurfactant producing bacteria more than $\mathrm{Pb}^{2+}$ and $\mathrm{Sr}^{2+}$ concentrations. For $\mathrm{Pb}^{2+}$ bonded to sulfate the most influential factor was biosurfactant producing bacteria followed with $\mathrm{Pb}^{2+}$ doses and $\mathrm{Sr}^{2+}$ doses. The most factors affected the content of $\mathrm{Pb}^{2+}$ in organic form was $\mathrm{Pb}^{2+}$ doses $>$ biosurfactant producing bacteria $>\mathrm{Sr}^{2+}$ doses. Finally, the total concentrations of $\mathrm{Pb}^{2+}$ in plant were affected with the associated of biosurfactant producing bacteria followed with $\mathrm{Sr}^{2+}$ doses and $\mathrm{Pb}^{2+}$ doses. In general, our results are not in harmony with Herman et al., 1995 in which (a rhamnolipid) biosurfactant was isolated from Pesudomonas aeruginosa, and investigated to remove $\mathrm{Cd}^{2+}, \mathrm{Pb}^{2+}$, and $\mathrm{Zn}^{2+}$ containing polluted soils. The addition of a rhamnolipid improved the desorption of $\mathrm{Pb}^{2+}$ by $43 \%$ compared with ion exchange treatments. In general, the effect of associated elements on the behavior of $\mathrm{Pb}^{2+}$ containing soil during the treatment with biosurfactant was unclear (Hogan et al., 2017).

The analysis of variance derived from Taguchi approach are listed in Tables (7-12). The obtained Ffactors values from the recommended tables were 3.15 and 4.78 at $\alpha$ (risk) levels of 0.05 and 0.01 , respectively. The obtained results showd that, the effect of $\mathrm{Pb}^{2+}$ doses were significant at $\alpha$ (risk) 0.01 towards the available 


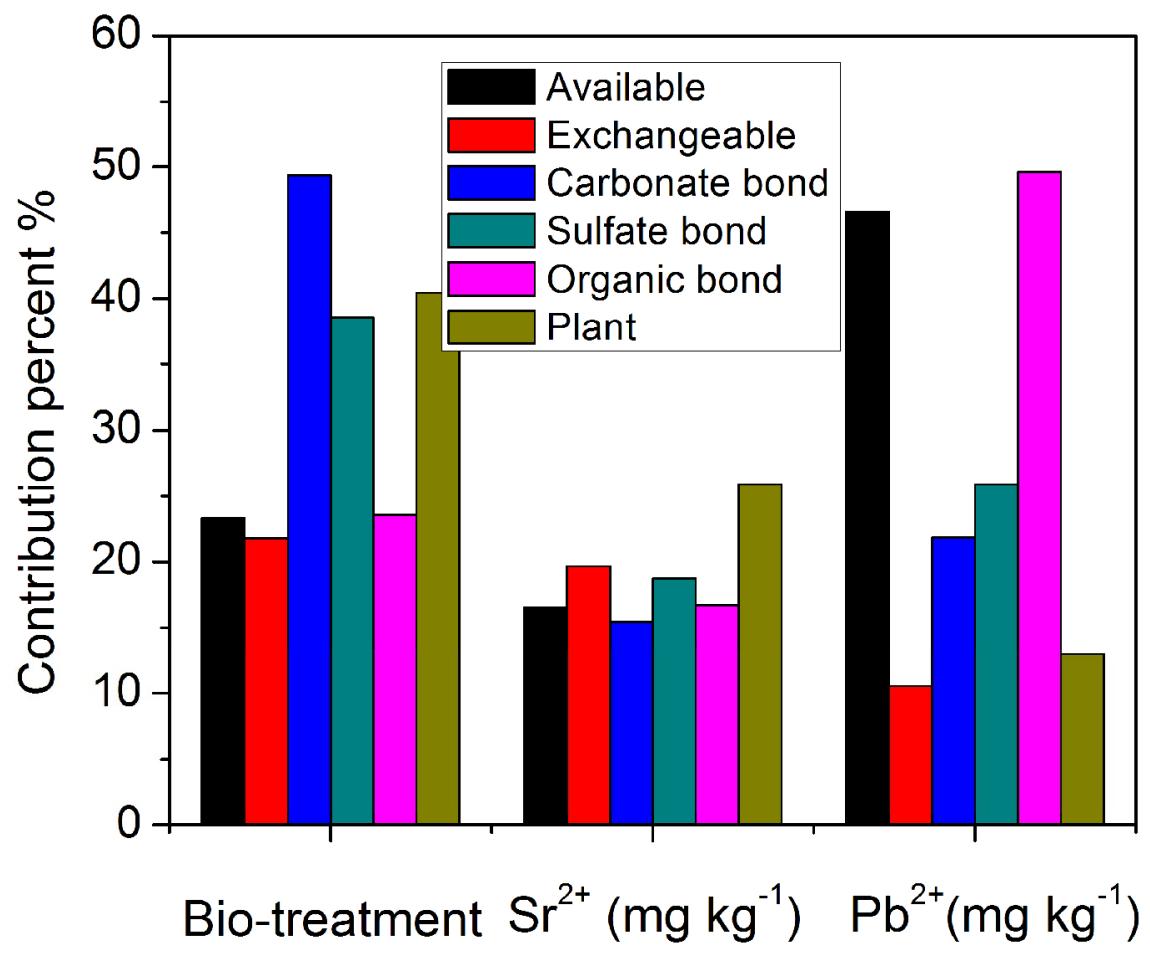

Fig. 8. The contribution percent of biosurfactant producing bacteria, $\mathrm{Sr}^{2+}$ doses, and $\mathrm{Pb}^{2+}$ doses towards different $\mathrm{Pb}^{2+}$ forms

Table 7. ANOVA analysis shows the significant effects of bacteria species, $\mathrm{Sr}^{2+}$ doses, and $\mathrm{Pb}^{2+}$ doses on the available form of $\mathbf{P b}^{2+}$

\begin{tabular}{lccccc}
\hline Factors & DOF & SS & V & F & P \\
\hline Bio-treatment & 4 & 22714.98 & 5678.745 & 2.142372 & 23.29902 \\
$\mathrm{Sr}^{2+}$ & 3 & 16105.86 & 5368.619 & 2.025374 & 16.51997 \\
$\mathrm{~Pb}^{2+}$ & 3 & 45419.03 & 15139.68 & 5.711619 & 46.58684 \\
Error & 5 & 13253.4 & 2650.681 & & \\
\hline Total & 15 & 97493.27 & & & \\
\hline
\end{tabular}

Table 8. ANOVA analysis shows the significant effects of bacteria species, $\mathrm{Sr}^{2+}$ doses, and $\mathrm{Pb}^{2+}$ doses on the exchangeable form of $\mathrm{Pb}^{2+}$

\begin{tabular}{lccccc}
\hline Factors & DOF & SS & V & F & P \\
\hline Bio-treatment & 4 & 0.776294 & 0.194073 & 0.566078 & 21.77217 \\
$\mathrm{Sr}^{2+}$ & 3 & 0.699999 & 0.233333 & 0.680591 & 19.63238 \\
$\mathrm{~Pb}^{2+}$ & 3 & 0.375047 & 0.125016 & 0.364649 & 10.51868 \\
Error & 5 & 1.714193 & 0.342839 & & \\
\hline Total & 15 & 3.565532 & & & \\
\hline
\end{tabular}

Table 9. ANOVA analysis shows the significant effects of bacteria species, $\mathrm{Sr}^{2+}$ doses, and $\mathrm{Pb}^{2+}$ doses on $\mathrm{Pb}^{2+}$ bond to carbonate

\begin{tabular}{lccccc}
\hline Factors & DOF & SS & V & F & P \\
\hline Bio-treatment & 4 & 32.05967 & 8.014917 & 4.610017 & 49.34581 \\
$\mathrm{Sr}^{2+}$ & 3 & 10.03208 & 3.344028 & 1.923417 & 15.44125 \\
$\mathrm{~Pb}^{2+}$ & 3 & 14.18469 & 4.72823 & 2.719581 & 21.83288 \\
Error & 5 & 8.692937 & 1.738587 & & \\
\hline Total & 15 & 64.96938 & & & \\
\hline
\end{tabular}


Table 10. ANOVA analysis shows the significant effects of bacteria species, $\mathrm{Sr}^{2+}$ doses, and $\mathrm{Pb}^{2+}$ doses on $\mathrm{Pb}^{2+}$ bond to sulfate

\begin{tabular}{lccccc}
\hline Factors & DOF & SS & V & F & P \\
\hline Bio-treatment & 4 & 731.4075 & 182.8519 & 2.873391 & 38.56897 \\
$\mathrm{Sr}^{2+}$ & 3 & 355.4714 & 118.4905 & 1.861996 & 18.74491 \\
$\mathrm{~Pb}^{2+}$ & 3 & 491.3024 & 163.7675 & 2.573492 & 25.90762 \\
Error & 5 & 318.1814 & 63.63628 & & \\
\hline Total & 15 & 1896.363 & & & \\
\hline
\end{tabular}

Table 11.ANOVA analysis shows the significant effects of bacteria species, $\mathrm{Sr}^{2+}$ doses, and $\mathrm{Pb}^{2+}$ doses $\mathrm{on}^{\mathrm{Pb}^{2+}}$ bond to organic materials

\begin{tabular}{lccccc}
\hline Factors & DOF & SS & V & F & P \\
\hline Bio-treatment & 4 & 279.4234 & 69.85586 & 2.911508 & 23.56911 \\
$\mathrm{Sr}^{2+}$ & 3 & 198.1329 & 66.04429 & 2.752647 & 16.71233 \\
$\mathrm{~Pb}^{2+}$ & 3 & 588.0279 & 196.0093 & 8.169431 & 49.59961 \\
Error & 5 & 119.9651 & 23.99302 & & \\
\hline Total & 15 & 1185.549 & & & \\
\hline
\end{tabular}

Table 12. ANOVA analysis shows the significant effects of bacteria species, $\mathrm{Sr}^{2+}$ doses, and $\mathrm{Pb}^{2+}$ doses on $\mathrm{Pb}^{2+}$ uptake by plant

\begin{tabular}{lccccc}
\multicolumn{1}{c}{ Factors } & DOF & SS & V & F & P \\
\hline Bio-treatment & 4 & 3480.978 & 870.2445 & 2.440584 & 40.43463 \\
$\mathrm{Sr}^{2+}$ & 3 & 2231.518 & 743.8392 & 2.086083 & 25.92104 \\
$\mathrm{~Pb}^{2+}$ & 3 & 1113.546 & 371.1821 & 1.040973 & 12.93482 \\
Error & 5 & 1782.861 & 356.5723 & & \\
\hline Total & 15 & 8608.903 & & & \\
\hline
\end{tabular}

form of $\mathrm{Pb}^{2+}$. The effects of bacteria species, $\mathrm{Sr}^{2+}$ doses, and $\mathrm{Pb}^{2+}$ doses on the exchangeable form of $\mathrm{Pb}^{2+}$ are not significant towards the exchangeable form of $\mathrm{Pb}^{2+}$. The effect of bacteria species was significant at $\alpha$ (risk) 0.05 towards $\mathrm{Pb}^{2+}$ bond to carbonate. The effects of $\mathrm{Sr}^{2+}$ doses, and $\mathrm{Pb}^{2+}$ doses were insignificant towards $\mathrm{Pb}^{2+}$ uptake by plant and $\mathrm{Pb}^{2+}$ bonded to sulfate. The effects of $\mathrm{Pb}^{2+}$ concentrations were significant at $\alpha$ (risk) 0.01 towards $\mathrm{Pb}^{2+}$ bond to organic materials.

Effect of biosurfactant producing bacteria on NPK uptake by watercress determined by Taguchi approach

The effects of biosurfactant producing bacteria, $\mathrm{Pb}^{2+}$ doses and $\mathrm{Sr}^{2+}$ doses on nitrogen $(\mathrm{N})$, phosphorous $(\mathrm{P})$, and potassium $(\mathrm{K})$ uptake by watercress is presented in Fig. (9). Table (13) lists the variations of NPK (\%) and its calculated $(\mathrm{S} / \mathrm{N})$ in the treated soil. Data presented in Fig. (9) shows the effect of surfactant producing bacteria on NPK uptake by watercress. The effect of biosurfactant producing bacteria, $\mathrm{Pb}^{2+}$ doses and $\mathrm{Sr}^{2+}$ doses did not show any noticeable effect on nitrogen uptake by watercress and the obtained result were almost the same with that obtained in the blank experiments.

The $P$. lubricantis bacteria did not affect the phosphorous uptake by watercress and showed the same tendency observed with the blank experiments. However, L. novalis bacteria and A. niger (crude biosurfactant) decreased phosphorous uptake by watercress. The mixture addition $(\mathrm{A}+\mathrm{B}+\mathrm{C})$ improved the phosphorous uptake by watercress again.

Fig. (9) illustrates that potassium uptake by watercress decreased compared with the blank experiment. However, the mixture addition showed the same tendency observed with phosphorous in which the mixture addition enhanced potassium uptake by watercress. Hogan et al., 2017 reported that $\mathrm{K}^{+}$and $\mathrm{Mg}^{2+}$ were weakly bonded with biosurfactant (rhamnolipid) compared with $\mathrm{Ca}^{2+}$ and $\mathrm{Fe}^{3+}$.

Data illustrated in Fig. (10) presents the effects of $\mathrm{Sr}^{2+}$ doses on the NPK uptake by watercress determined by Taguchi approach. Different doses of $\mathrm{Sr}^{2+}$ did not markedly show any impact on the nitrogen uptake by watercress. Increasing $\mathrm{Sr}^{2+}$ doses at $3 \mathrm{mg} \mathrm{kg}^{-1}$ and $5 \mathrm{mg}$ $\mathrm{kg}^{-1}$ decreased phosphorous uptake by watercress, however at higher concentrations of $10 \mathrm{mg} \mathrm{kg}^{-1}$ the phosphorous uptake by watercress increased again. Potassium uptake by watercress was significantly decreased with deferent doses of $\mathrm{Sr}^{2+}$ varied from 0-10 $\mathrm{mg} \mathrm{kg}{ }^{-1}$. The effects of $\mathrm{Pb}^{2+}$ doses on NPK uptake by watercress are presented in Fig. 11. The obtained results indicated that the same tendency obtained with biosurfactant producing bacteria and $\mathrm{Sr}^{2+}$ doses for nitrogen uptake by watercress was observed, in which there was no substantial variation in nitrogen uptake with different $\mathrm{Pb}^{2+}$ doses. The phosphorous uptake by 
watercress was increased when $\mathrm{Pb}^{2+}$ doses were increased from $50 \mathrm{mg} \mathrm{kg}^{-1}$ to $100 \mathrm{mg} \mathrm{kg}^{-1}$.

Table 13.The variations of NPK uptake by watercress $(\%)$ and its calculated $(\mathrm{S} / \mathrm{N})$ in the treated soil

\begin{tabular}{|c|c|c|c|c|c|}
\hline \multicolumn{2}{|c|}{ Nitrogen } & \multicolumn{2}{|c|}{ Phosphorous } & \multicolumn{2}{|c|}{ Potassium } \\
\hline $\mathrm{N}(\%)$ & $\mathrm{S} / \mathrm{N}$ ratio & $\mathrm{P}(\%)$ & $\mathrm{S} / \mathrm{N}$ ratio & $\mathrm{K}(\%)$ & $\mathrm{S} / \mathrm{N}$ ratio \\
\hline 65.63 & 36.34 & 15.47 & 23.79 & 33.27 & 30.44 \\
\hline 68.75 & 36.75 & 36.21 & 31.18 & 22.48 & 27.04 \\
\hline 68.75 & 36.75 & 44.50 & 32.97 & 26.61 & 28.50 \\
\hline 75.00 & 37.5 & 34.65 & 30.79 & 31.25 & 29.90 \\
\hline 78.13 & 37.86 & 44.66 & 33.00 & 43.95 & 32.86 \\
\hline 68.75 & 36.75 & 34.13 & 30.66 & 23.49 & 27.42 \\
\hline 68.75 & 36.75 & 18.65 & 25.41 & 37.80 & 31.55 \\
\hline 78.13 & 37.86 & 46.01 & 33.26 & 23.49 & 27.42 \\
\hline 75.00 & 37.50 & 49.61 & 33.91 & 49.19 & 33.84 \\
\hline 78.13 & 37.86 & 35.90 & 31.10 & 38.21 & 31.64 \\
\hline 75.00 & 37.50 & 30.59 & 29.71 & 25.00 & 27.96 \\
\hline 71.88 & 37.13 & 22.77 & 27.15 & 19.15 & 25.64 \\
\hline 68.75 & 36.75 & 50.02 & 33.98 & 59.07 & 35.43 \\
\hline 68.75 & 36.75 & 21.15 & 26.51 & 25.71 & 28.20 \\
\hline 81.25 & 38.20 & 35.80 & 31.08 & 26.11 & 28.34 \\
\hline 75.00 & 37.50 & 62.27 & 35.89 & 63.10 & 36.00 \\
\hline
\end{tabular}

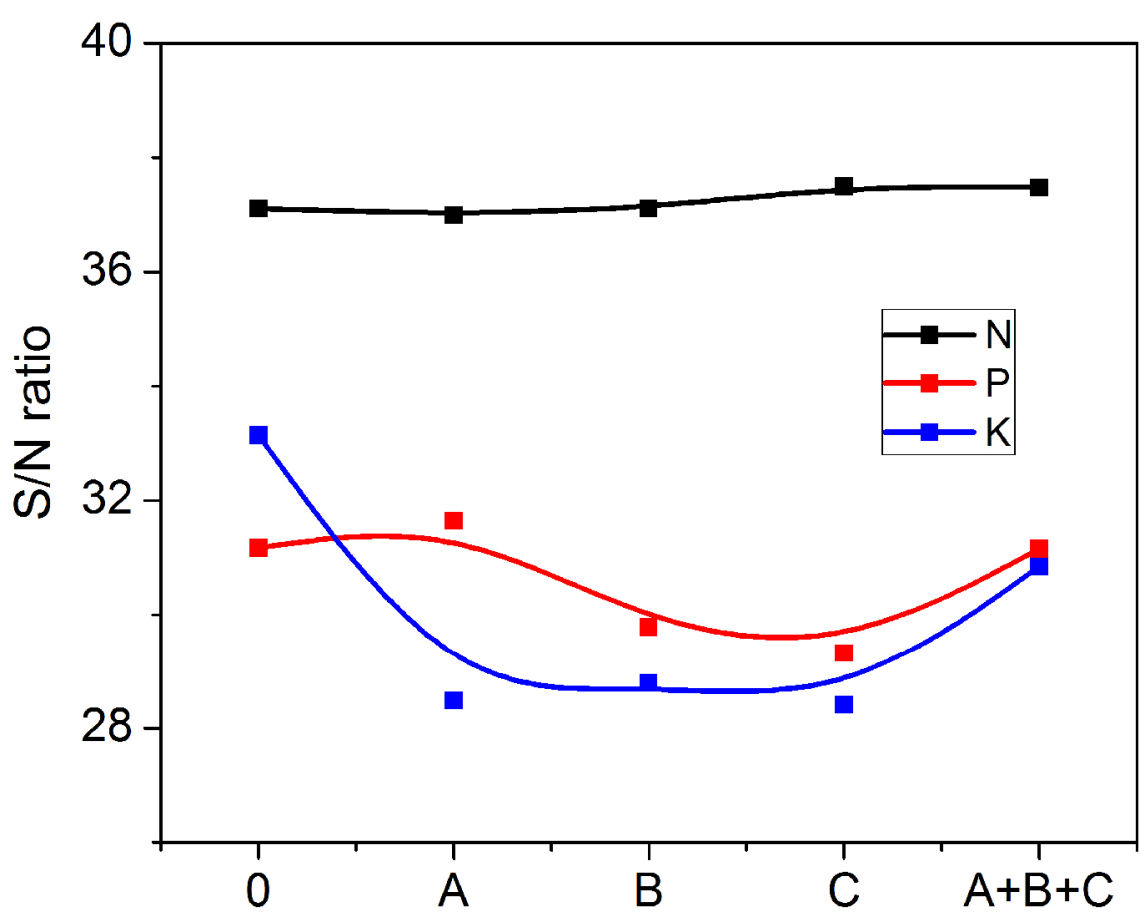

Bio-treatment

Fig. 9. Effect of biosurfactant producing bacteria on the NPK uptake by watercress ( $\mathrm{S} / \mathrm{N}$ is signal to noise ratio) 


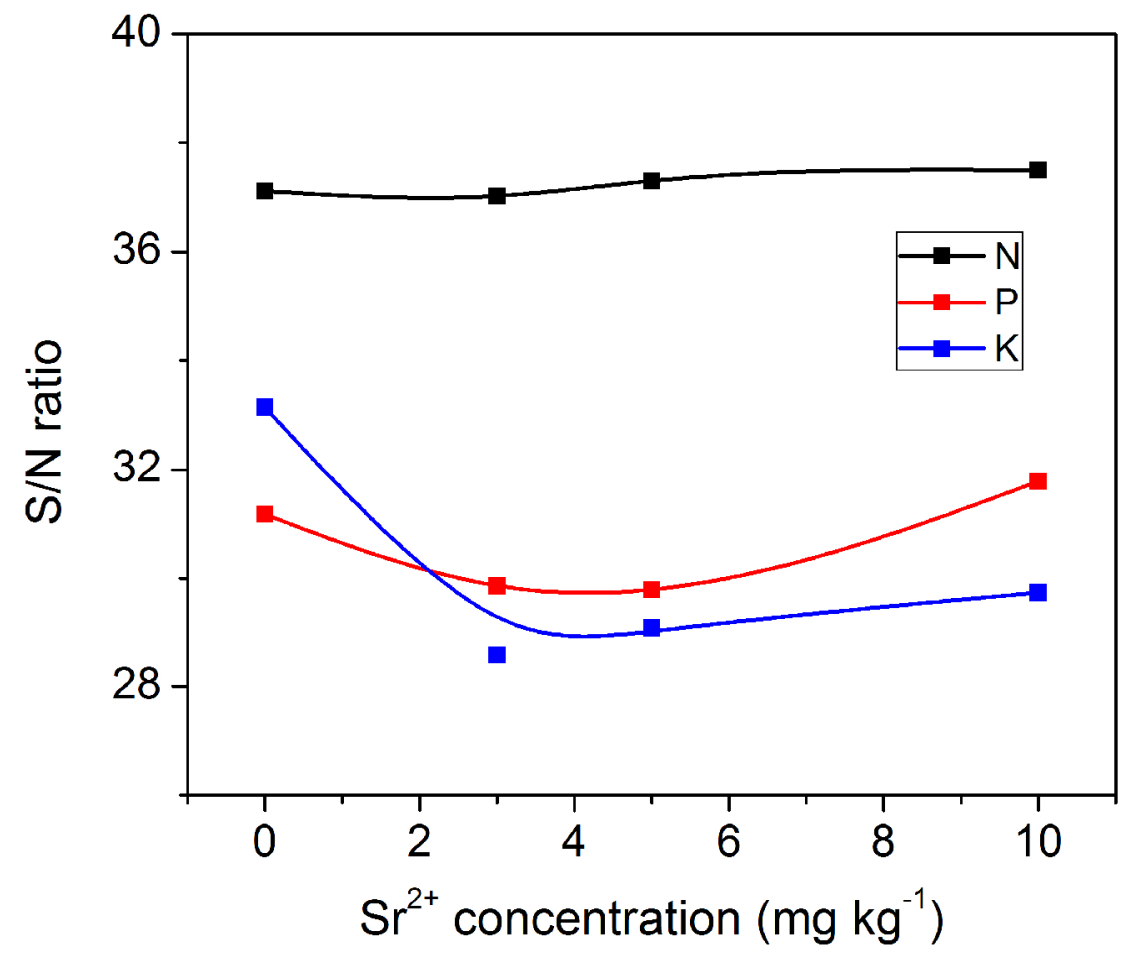

Fig. 10. Effect of $\mathrm{Sr}^{2+}$ doses on NPK uptake by watercress ( $\mathrm{S} / \mathrm{N}$ is signal to noise ratio)

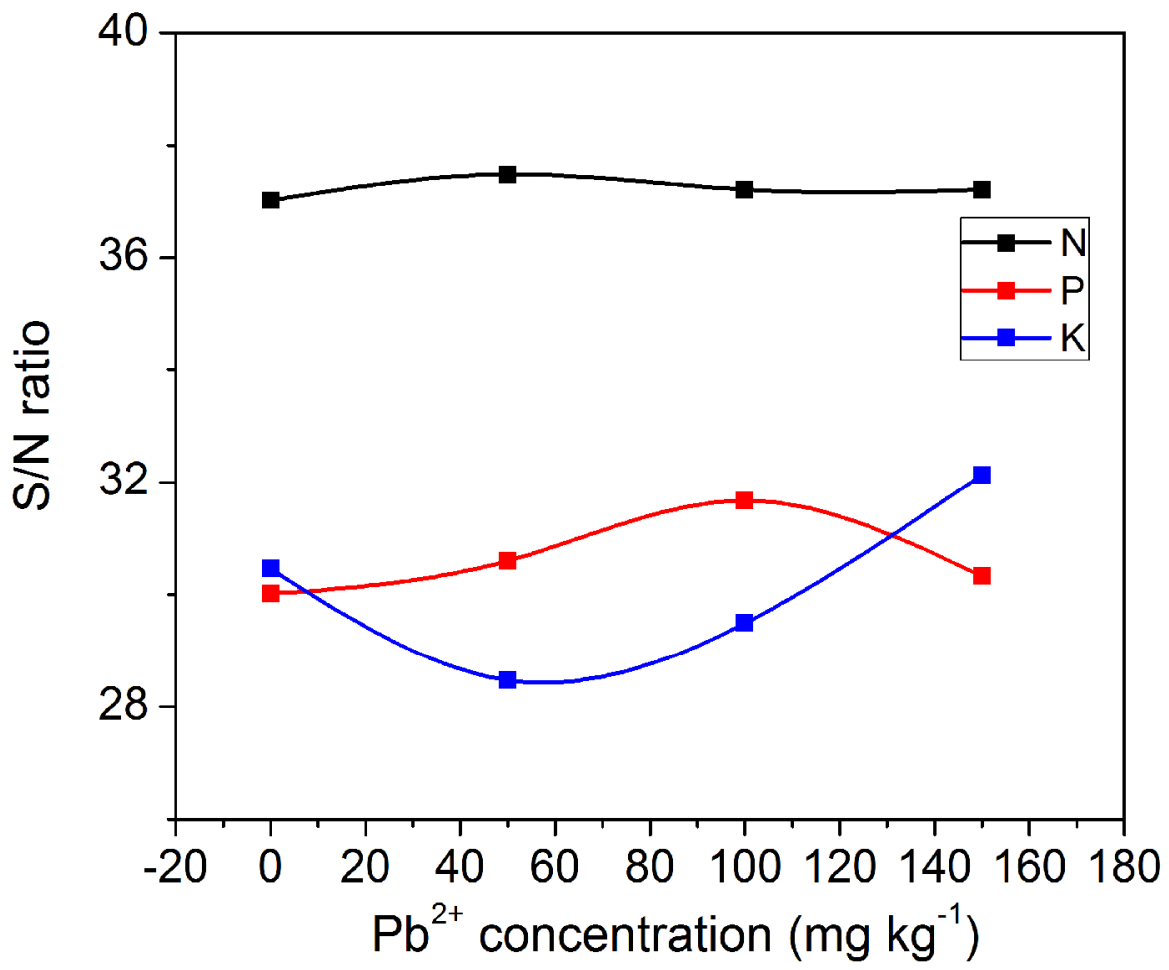

Fig. 11. Effect of $\mathbf{P b}^{2+}$ doses on NPK uptake by watercress ( $\mathrm{S} / \mathrm{N}$ is signal to noise ratio)

At high concentrations of $\mathrm{Pb}^{2+}$ doses $\left(150 \mathrm{mg} \mathrm{kg}^{-1}\right)$ the phosphorous uptake by watercress was reduced to be close with what was observed at $\mathrm{Pb}^{2+}$ doses of $50 \mathrm{mg}$ $\mathrm{kg}^{-1}$. The potassium uptake by watercress was deceased when $\mathrm{Pb}^{2+}$ doses increased from $50 \mathrm{mg} \mathrm{kg}^{-1}$ to $100 \mathrm{mg}$ $\mathrm{kg}^{-1}$. Noticeably, potassium uptake by watercress was 
quit high at $150 \mathrm{mg} \mathrm{kg}^{-1}$ of $\mathrm{Pb}^{2+}$ doses. Fig. (12) shows the contribution percent of biosurfactant producing bacteria, $\mathrm{Sr}^{2+}$ concentrations, and $\mathrm{Pb}^{2+}$ concentrations towards NPK uptake by watercress determined by Taguchi approach. The most influential factors affected NPK uptake by watercress were found to take the following sequence biosurfactant producing bacteria $>$ $\mathrm{Sr}^{2+}$ doses $>\mathrm{Pb}^{2+}$ doses. Tables (14-16) show the analysis of variance (ANOVA) for the effects of bacteria species, $\mathrm{Sr}^{2+}$ doses, and $\mathrm{Pb}^{2+}$ doses. The exchangeable form of $\mathrm{Pb}^{2+}$ were not significant towards nitrogen and phosphorous uptake by watercress. The effects of mixture addition $(\mathrm{A}+\mathrm{B}+\mathrm{C})$ and $\mathrm{Sr}^{2+}$ doses on potassium uptake by watercress were significant at $\alpha$ (risk) 0.01 .

It's clear seen from Figs. ( 8 and 12) that the contribution percent of biosurfactant producing bacteria was the highest during $\mathrm{Pb}^{2+}$ uptake by watercress and
$\left(\mathrm{N}, \mathrm{P}\right.$, and $\mathrm{K}$ ) uptake by plant compared with $\mathrm{Sr}^{2+}$ and $\mathrm{Pb}^{2+}$ doses. Based on literature review, the effects of biosurfactant on plant morphology and physiology aspects are absent. Ongoing researches are intended to investigate the impact of surfactant substances produced from either naturally or artificially sources and the results will be published soon. Regarding the effect of naturally produced surfactant on $\mathrm{Sr}^{2+}$ availability, we believe that the high mobility of $\mathrm{Sr}^{2+}$ can be exploited as an assistant tool during soil electrokinetic remediation using perforated cathode pipe SEKR (PCPSS). The outlet discharge will be treated simultaneously using electrolysis, electrodialysis, electrodeionization, and adsorption as it previously discussed in our previous work and the obtained date will be published soon (Bi et al., 2011, Almeria et al., 2012a; Almeria et al., 2012b; Abou-Shady et al., 2012a; Abou-Shady et al., 2012b; Peng et al., 2013; Abou-Shady et al. 2018).

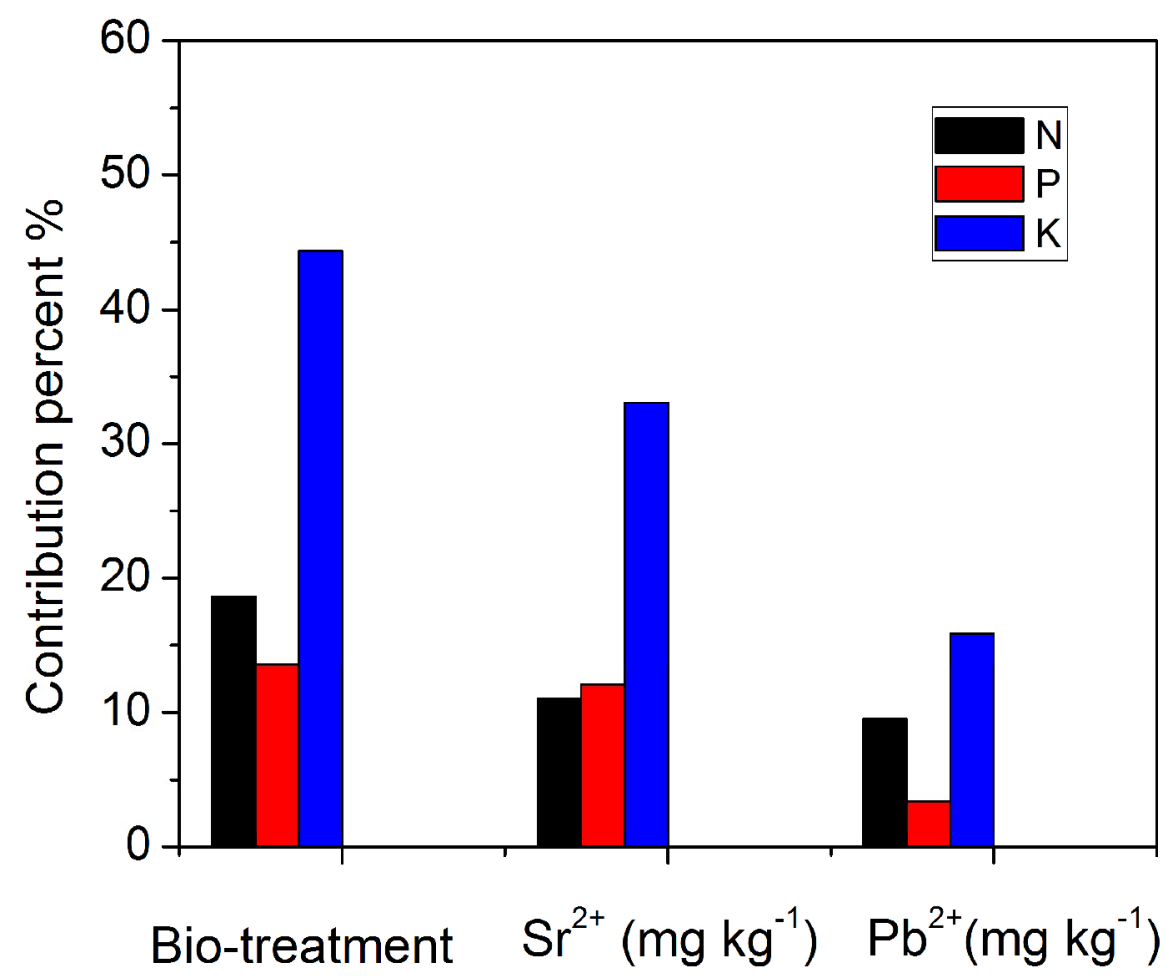

Fig. 12. The contribution percent of biosurfactant producing bacteria, $\mathrm{Sr}^{2+}$ concentrations, and $\mathrm{Pb}^{2+}$ concentrations towards NPK uptake by watercress

Table 14. ANOVA analysis shows the significant effects of bacteria species, $\mathrm{Sr}^{2+}$ doses, and $\mathrm{Pb}^{2+}$ doses on nitrogen uptake by watercress

\begin{tabular}{lccccc}
\hline Factors & DOF & SS & V & F & P \\
\hline Bio-treatment & 4 & 60.76389 & 15.19097 & 0.382383 & 18.60852 \\
$\mathrm{Sr}^{2+}$ & 3 & 36.01074 & 12.00358 & 0.302151 & 11.02804 \\
$\mathrm{~Pb}^{2+}$ & 3 & 31.12793 & 10.37598 & 0.261181 & 9.53271 \\
Error & 5 & 198.6355 & 39.72711 & & \\
\hline Total & 15 & 326.5381 & & & \\
\hline
\end{tabular}


Table 15. ANOVA analysis shows the significant effects of bacteria species, $\mathrm{Sr}^{2+}$ doses, and $\mathrm{Pb}^{2+}$ doses on phosphorous uptake by watercress

\begin{tabular}{lccccc}
\hline Factors & DOF & SS & V & F & P \\
\hline Bio-treatment & 4 & 335.451 & 83.86274 & 0.239354 & 13.5848 \\
$\mathrm{Sr}^{2+}$ & 3 & 298.4892 & 99.49641 & 0.283974 & 12.08796 \\
$\mathrm{~Pb}^{2+}$ & 3 & 83.51467 & 27.83822 & 0.079454 & 3.382104 \\
Error & 5 & 1751.856 & 350.3712 & & \\
\hline Total & 15 & 2469.311 & & & \\
\hline
\end{tabular}

Table 16. ANOVA analysis shows the significant effects of bacteria species, $\mathrm{Sr}^{2+}$ doses, and $\mathrm{Pb}^{2+}$ doses on potassium uptake by watercress

\begin{tabular}{lccccc}
\hline Factors & DOF & SS & V & F & P \\
\hline Bio-treatment & 4 & 1191.675 & 297.9187 & 8.250617 & 44.37122 \\
$\mathrm{Sr}^{2+}$ & 3 & 886.8599 & 295.62 & 8.186954 & 33.02163 \\
$\mathrm{~Pb}^{2+}$ & 3 & 426.6154 & 142.2051 & 3.938255 & 15.88474 \\
Error & 5 & 180.5433 & 36.10866 & & \\
\hline Total & 15 & 2685.694 & & &
\end{tabular}

\section{CONCLUSIONS}

The effects of biosurfactant producing microorganisms on heavy metal containing polluted soils were studied in terms of leaching columns and agriculture experiments designed using Taguchi approach $\left(\mathrm{L}_{16} \mathrm{OA}\right)$. The results showed that, the biosurfactant producing bacteria controlled the mobility of $\mathrm{Pb}^{2+}$ and $\mathrm{Sr}^{2+}$ in the treated soils. $\mathrm{Pb}^{2+}$ was adsorbed/ precipitated in the treated soils and in contrast $\mathrm{Sr}^{2+}$. Results obtained from Taguchi approach indicated that, the mechanisms of biosurfactant producing bacteria on $\mathrm{Pb}^{2+}$ was very complicated and interfusion with each other. Generally, the most factors affected the available form of $\mathrm{Pb}^{2+}$ and $\mathrm{Pb}^{2+}$ existed in organic form was $\mathrm{Pb}^{2+}$ concentrations, however for exchangeable form, carbonate form, sulfate form, and plant content the most influenced factors was biosurfactant producing bacteria. The most influential factors affected NPK uptake by watercress were found to take the following sequence biosurfactant producing bacteria $>\mathrm{Sr}^{2+}$ doses $>\mathrm{Pb}^{2+}$ doses.

\section{ACKNOWLEDGMENTS}

This work was supported by Desert Research Center Research No: 1822.

\section{REFERENCES}

Abou-Shady, A. 2008. Effect of humic substance on the behaviors of heavy metals in alluvial and calcareous soils, M.Sc, dissertation, Minufiya University, Egypt.

Abou-Shady, A. 2012. Removal of $\mathrm{Pb}$ (II) from wastewater and polluted soil by electrical technologies. PhD Dissertation, Ocean University of China, China.

Abou-Shady, A. 2016a. Effect of separated cathode on the removal of dissolved organic carbon using anode oxidation, Fenton oxidation, and coagulation, J. Environ. Chemi. Engineer. 4 (1): 704-710.

Abou-Shady, A. 2016b. Reclaiming salt-affected soils using electro-remediation technology: PCPSS evaluation. Electrochimica Acta. 190: 511-520.

Abou-Shady, A. 2017. Recycling of polluted wastewater for agriculture purpose using electrodialysis: Perspective for large scale application, Chemi. Engineer. J. 323: 1-18.

Abou-Shady, A. and C. Peng. 2012. New process for ex-situ electrokinetic pollutant removal I: process evaluation. J. Ind. Eng. Chem. 18: 2162-2176.

Abou-Shady, A. Eissa, D. Abdelmottaleb, O. and H. Rehab. 2018. New approaches to remediate heavy metals containing polluted soil via improved PCPSS. J. Environ. Chemi. Engineer. 6: 1322-1332.

Abou-Shady, A., Peng, C., Almeria O.J. and H. Xu. 2012b. Effect of $\mathrm{pH}$ on separation of $\mathrm{Pb}$ (II) and NO3 from aqueous solutions using electrodialysis, Desalination. 285 (2012) 46-53.

Abou-Shady, A., Peng, C., Bi, J., Xu, H. and J. Almeria. 2012a. Recovery of $\mathrm{Pb}$ (II) and removal of NO3 from aqueous solutions using integrated electrodialysis, electrolysis, and adsorption process, Desalination. 286: 304-315.

Almeria O J., Peng C., and A. Abou-Shady. 2012a. Simultaneous removal of cadmium from kaolinite and catholyte using electrokinetic process, Desalination.. 300: 1-11.

Almeria, J.O. Peng, C. and A. Abou-Shady. 2012b. Enhancement of ion transport in porous media by the use of a continuously-reoriented electric field, J Zhejiang Univ-Sci A (Appl Phys \& Eng). 13 (7): 546-558. 
Anandaraj. B. and P. Thivakaran. 2010. Isolation and production of biosurfactant producing organism from oil spilled soil. J.Biosci.Tech.3:120-126.

Bernheimer, A.W. and L.S. Avigad. 1970. Nature and properties of a cytolytic agent produced by Bacillus subtilis. J. Gen. Microbiol. 61(3):361-9.

Bi, J. Peng, C. Xu, H. and A. Ahmed. 2011. Removal of nitrate from groundwater using the technology of electrodialysis and electrodeionization, Desalin. Water Treat. 34: 394-401.

Bodour, A., Gerrero-Barajas, C. and M. Maier. 2004. Structure and characterization of Flavolipids, a novel class of Biosurfactants produced by Flavolipid sp. Strain MTN11. App and Env Microbiol. 10(6): 1114-1120.

Chen, H.-R., Chen, C.-C. A., Reddy, S., Chen, C.-Y.,Li, W. R. Tseng, M.-J., Liu, H.-T., Pan, W., Maity, J.P. and S.B. Atla. 2011. Removal of mercury by foam fractionation using surfactin, a biosurfactant. Inter. J. Molecular Sci. 12: 8245-8258.

Eissa, D. A. Abou-Shady, Ismaeil S. and N. Bahnasawy. 2017. Distribution and mobility of vanadium in cultivated calcareous soils and some food chain crops, EJSS. 57 (4): 385-392.

Elouzi, A. Akasha, A. Elgerbi, A. El-Baseir, M. and B. El Gammudi. 2012. Removal of Heavy Metals Contamination by bio-Surfactants (Rhamnolipids), Journal of Chemical and Pharmaceutical Research. 4(9): 4337-4341.

Felsenstein, J. 1993. Phylogeny Inference Package (PHYLIP). Version 3.5. University of Washington, Seattle.

Franzetti, A, Gandolfi, I. Fracchia, L. Hamme, J. Gkorezis, P. Marchant, R. and I. Banat. 2014. Biosurfactant Use in Heavy Metal Removal from Industrial Effluents and Contaminated Sites. 361196.

Hall, T.A. 1999. BioEdit: A User-Friendly Biological Sequence Alignment Editor and Analysis Program for Windows 95/98/NT. Nucleic Acids Symposium Series. 41, 95-98.

Herman, D. Artiola, J. and R. Miller. 1995. Removal of cadmium, lead, and zinc from soil by a rhamnolipid biosurfactant. Soil, Water, and Environmental Science. 9: 2280-2285.

Hogan, D.E, Curry, J.E. Pemberton, J.E. and R.M. Maier. 2017. Rhamnolipid biosurfactant complixation of rare earth elements. J. Haz. Mat. 340: 171-178.

Hong, K.-J. Choi, Y.-K. Tokunage, S. Ishigami, Y. and T. Kajiuchi. 1997. Removal of cadmium and lead from soil using aescin as a biosurfactant. Journal of Surfactants and Detergents. 1 (2): 247-250.

Huang, W. and Z.M. Liu. 2013. Biosorption of $\mathrm{Cd}(\mathrm{II}) / \mathrm{Pb}(\mathrm{II})$ from aqueous solution by biosurfactant-producing bacteria: Isotherm kinetic characteristic and mechanism studies. Colloids and Surfaces B: Biointerfaces. 105: 113-119.

Ishikawa. M, Janda. M. and P. Ahlquist. 2000. The 3a cell-to-cell movement gene is dispensable for cellto-cell transmission of brome mosaic virus RNA replicons in yeast but retained over 10(45)-fold amplification. J. Gen. Virol. 81: 2307-231.

Jackson, M. L. (1973) Soil Chemical Analysis, Prentice Hall, England, U.K.

Jin, R. Peng, C. Abou-Shady, A. and K. Zhang. 2012. Recovery of precious metal material $\mathrm{Ni}$ from nickel containing wastewater using electrolysis, Applied Mechanics and Materials. 164: 263-267.

Johnson, M. K. and D. Boese-Marrazzo. 1980. Production and properties of heat-stable extracellular hemolysin from Pseudomonas aeruginosa. Infect. Immun. 9(3): 1028-1033.

Khalil, R. Abou-Hussien, E. Radwan, S. and A. Aboushady. 2009. Distribution of humic and fulvic acids in alluvial and calcareous soils. Minufiya J. Agric. Res. 1 (34): 311-324.

Miller, R. 1995. Biosurfactant Facilitated Remediation of Metal-contaminated Soils, Environ. Health Perspectives. 103: 59-62.

Moran, M.M. McFarland, K. Melendez, R.I. Kalivas, P.W. and J.K. Seamans. 2005. Cystine/glutamate exchange regulates metabotropic glutamate receptor presynaptic inhibition of excitatory transmission and vulnerability to cocaine seeking. J. Neurosci. 25:6389-6393.

Morikawa M, Daido H, Takao T, Murata S, Shimonishi Y. and T. Imanaka. 1993. A new lipopeptide biosurfactant produced by Arthrobacter sp. strain MIS38. J Bacteriol. 175(20):6459-66.

NCBI website: (Wwww.ncbi.nlm.nih.gov/bist)

Peng, C. Almeria, J.O. and A. Abou-Shady. 2013. Enhancement of ion migration in porous media by the use of varying electric fields, Sep. Purif. Technol. 118C: 591-597.

Peng, C. Liu, Y. Bi, J. Xu, H. and A. Ahmed. 2011. Recovery of copper and water from copperelectroplating wastewater by the combination process of electrolysis and electrodialysis. J. Haz. Mater. 189: 814-820.

Pitt, J. and A. Hocking. 2009. Fungi and Food Spoilage. Springer Dordrecht Heidelberg London New York. 
Pruthi, V. and S. Cameotra. 1997. Production of a biosurfactant exhibiting excellent emulsification and surface active properties by Serratia marcescens. World. J. Microbiol. biotechnol. 13:133-135.

Rajkumar, M., Sandhya, S., Prasad, M.N.V. and H. Freitas. 2012. Perspectives of plant-associated microbes in heavy metal phytoremediation. Biotechnol. Advan. 30: 1562-1574.

Saitou, N, and M. Nei. 1987. The neighbor-joining method: a new method for reconstructing phylogenetic trees. Mol Biol Evol. 4(4): 406-425.

Sanders, E.R. 2012.Aseptic Laboratory Techniques: Plating Methods. J. Vis. Exp. 63: 3791-3064.

Saravanan V. and S. Vijayakumar. 2012. Isolation and screening of biosurfactant producing microorganisms from oil contaminated soil. J. Acad. Indus. Res. 1(5) 264-268.

Satpute, S., Bhawsar, B., Dhakephalkar, P. and B. Chopade. 2008. Assessment of different screening methods for selecting biosurfactant producing marine bacteria. Indian J. Mar. Sci. 37 (3): 243-250.
Siegmund, I. and F. Wagner. 1991. New method for detecting rhamnolipids excreted by Pseudomonas spe cies during growth on mineral agar. Biotechnol. Tech. 5: 265-268.

Slizovskiy, I.B., Kelsey, J.W. and P.B. Hatzinger. 2011. Surfactant-facilitated remediation of metal contaminated soils: Efficacy and toxicological consequences to earthworms. Environ. Toxicol. Chemi. 30: 112-123.

Tessier, P.G., Campbell, C. and M. Bisson. 1979. Sequential extraction procedure for speciation of particulate trace metals. Analyt. Chem. 51, 844851.

Yuan, X.Z., Meng, Y.T., Zeng, G.M., Fang, Y.Y. and J.G. Shi. 2008. Evaluation of tea-derived biosurfactant on removing heavy metal ions from dilute wastewater by ion flotation. Colloids and Surfaces a-Physico chemical and Engineering Aspects. 317: 256-261.

Zouboulis, A.I., Matis, K.A., Lazaridis, N.K. and P.N. Golyshin. 2003. The use of biosurfactants in flotation: Application for the removal of metal ions. Minerals Engineer. 16: 1231-1236.

\title{
الملخص العربي
}

\section{اضافة الكائنات الدقيقة المنتجة للمركبات الحيوية النشطة سطحيا لمعالجة التلوث بالعناصر الثقيلة بمنطقة \\ الجب!ل الاصفر}

\author{
رابعة خليفة، سماح عبد العزيز ، دعاء عيسى ، أحمد أبو شادى الاصى
}

Lysobacter novalis (B), and Aspergillus niger (C)

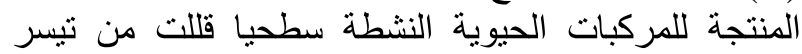

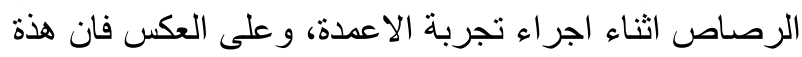

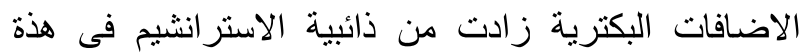

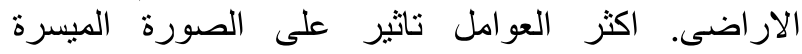

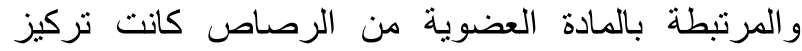

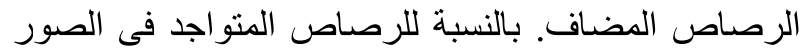

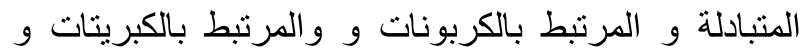

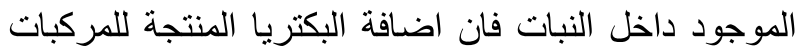

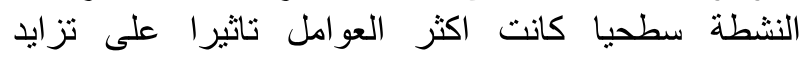

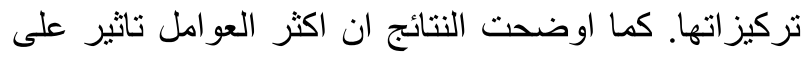

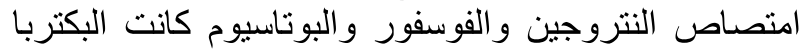

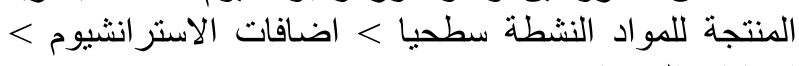

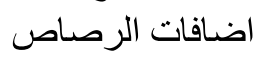

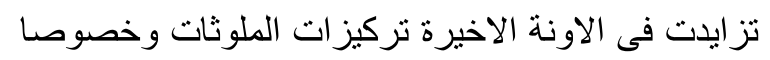

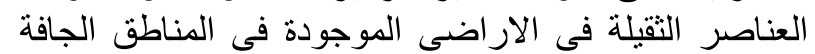

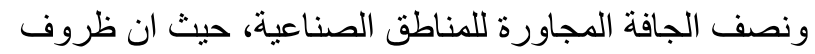

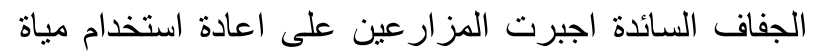

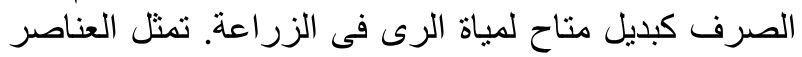

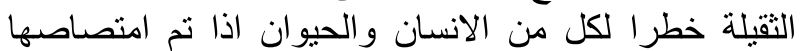

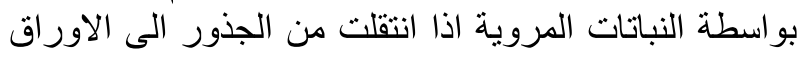

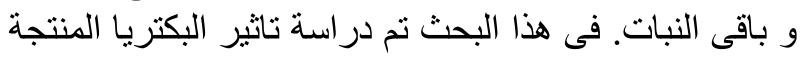

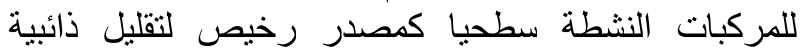

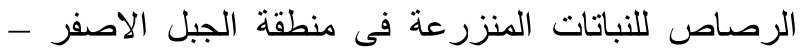

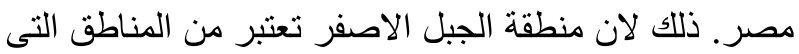

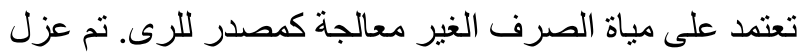

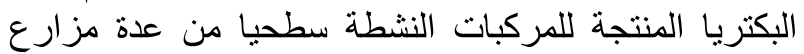

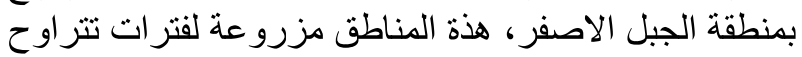

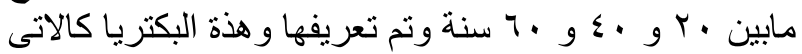
Pseudochrobactrum lubricantisa (A), 